Review

\title{
Minimal residual disease using liquid biopsies in hematologi- cal malignancies
}

\author{
Rafael Colmenares ${ }^{1}$, Noemí Álvarez ${ }^{\text {, }}$ Santiago Barrio ${ }^{1,2}$, Joaquín Martínez-López ${ }^{1,2,3,4}$ and Rosa Ayala ${ }^{1,2,3,4 *}$ \\ 1 Hematology Department, Hospital Universitario 12 de Octubre, Instituto de Investigación Sanitaria \\ Imas12, 28041 Madrid, Spain; rafael.colmenares@salud.madrid.org (R.C.); noalva01@ucm.es (N.A.); san-

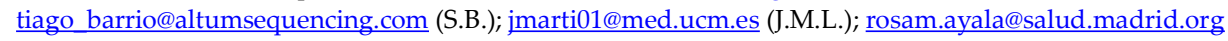 \\ (R.A.) \\ 2 Hematological Malignancies Clinical Research Unit, CNIO, 28029 Madrid, Spain \\ 3 Departament of Medicine, Complutense University, 28040 Madrid, Spain \\ 4 Centro de Investigación Biomédica en Red de Cáncer (CIBERONC), Instituto Carlos III, 28029 Madrid, \\ Spain \\ * $\quad$ Correspondence: rosam.ayala@salud.madrid.org (R.A.); Tel.: (+34)917792788
}

Simple Summary: Monitoring the response to treatment in hematologic malignancies is essential in defining the best way to optimize patient management. In general, achieving a deeper response has been shown to lead to a better prognosis, and the techniques used to study minimal residual disease (MRD) are becoming more precise. The use of liquid biopsies, that is, analyzing the presence of alterations in nucleic acids, usually in peripheral blood or other biological fluids, is being studied and optimized with increasingly innovative molecular techniques, such as next-generation sequencing (NGS) in the monitoring of MRD, avoiding, in many cases, more invasive tests in different hematological neoplasms. Currently, liquid biopsies are not standardized for MRD monitoring, but there is increasing evidence of its correlation with other techniques to measure response to treatment and with patient outcomes.

\begin{abstract}
The study of cell-free DNA (cfDNA) and other peripheral blood components (known as "liquid biopsies") is promising and has been investigated especially in solid tumors. Nevertheless, it is increasingly showing greater utility in the diagnosis, prognosis, and response to treatment of hematological malignancies; in the future, it could prevent invasive techniques, such as bone marrow (BM) biopsy. Most of the studies about this topic have been focused on B cell lymphoid malignancies; some of them have shown that cfDNA can be used as a novel way for diagnosis and minimal residual monitoring in B cell lymphomas, using techniques such as next-generation sequencing (NGS). In myelodysplastic syndromes, multiple myeloma, or chronic lymphocytic leukemia, liquid biopsies may allow for an interesting genomic representation of the tumor clones affecting different lesions (spatial heterogeneity). In acute leukemias, it can be helpful in the monitoring of early treatment response and the prediction of treatment failure. In chronic lymphocytic leukemia, the evaluation of cfDNA permits the definition of clonal evolution and drug resistance in real time. However, there are limitations such as the difficulty in obtaining sufficient circulating tumor DNA for achieving a high sensitivity to assess minimal residual disease or the lack of standardization of the method and clinical studies to confirm its prognostic impact. This review focuses on clinical applications of cfDNA on minimal residual disease in hematological malignancies.
\end{abstract}

Keywords: cell-free DNA; liquid biopsy; cancer; next-generation sequencing (NGS); minimal residual disease; measurable residual disease; molecular residual disease (MRD); leukemia; lymphoma; myeloma; myeloproliferative neoplasms; myelodysplastic syndrome 


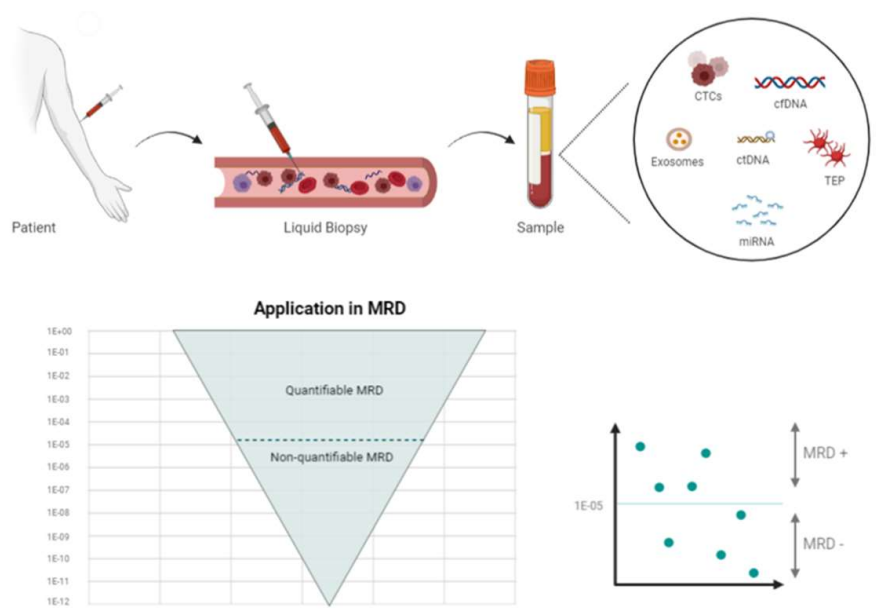




\section{Introduction}

Hematological malignancies are the result of molecular alterations that affect the genes involved in cell growth and proliferation. Sometimes, the molecular profile of a tumor is obtained only by analyzing a small portion, as in lymphomas, which can lead to loss of information, because of the heterogeneity of the tumor or the presence of multiple tumor sites. In addition, it may sometimes be difficult to obtain a good sample to analyze, involving invasive procedures and increasing the risk to the patient, and monitoring the tumor by repeat biopsies is usually not feasible [1].

Various studies have shown that the blood contains remnants of some tissues, including tumor tissues. The term "liquid biopsy" is an attempt to approximate the molecular profile of a tumor by analyzing the peripheral blood by different methods: Circulating tumor cells (CTCs), cell-free circulating nucleic acids (DNA, mRNA, micro-RNA, or non-coding RNA), "tumor-educated platelets" (TEPs), or exosomes [2,3].

\subsection{Liquid biopsy components}

\subsubsection{Circulating tumor cells (CTCs)}

CTCs come from tumors as an early step in blood-borne metastasis. CTCs are transient in blood, with a half-life of 1-2.4 hours and presented in low abundance in most patients. Various techniques have been defined to isolate and analyze CTCs. These cells can even be used to establish cell line models to carry out therapeutic studies [4].

In hematological malignancies, analysis of CTCs is possible in leukemias (AML and ALL), myelodysplastic syndromes (MDSs), myeloproliferative neoplasms (MPNs), multiple myeloma (MM), and some lymphomas, such as mantle cell lymphoma (MCL), follicular lymphoma (FL), marginal zone lymphoma, small lymphocytic lymphoma, and a subset of Burkitt lymphoma. In contrast, diffuse large B cell lymphoma (DLBCL) and classical Hodgkin lymphoma (cHL) do not typically harbor CTCs [5].

\subsubsection{DNA in liquid biopsies}

The existence of cell-free DNA (cfDNA) was first described in 1948, and some studies have reported a higher amount of cfDNA in patients with cancer [6-8]. Initially, some reports have identified apoptosis or necrosis, or both, as the main source of cfDNA. During apoptosis, the chromosomes are trimmed by DNases into multiple nucleosomal units of $180 \mathrm{bp}$ that are released into the blood stream. These fragments "circulate" for one to three hours before they are ingested by phagocytes and other cells, where the cfDNA is completely digested into nucleotides by lysosomes [9]. Necrosis causes random nonspecific and incomplete digestion of DNA. Some studies have suggested that DNA may be released by living cells [10-12].

This review is focused on ctDNA and cfDNA: There are differences between these concepts. cfDNA fragments are longer, with a size range of 160-180 bp, indicating a caspase-dependent apoptotic cleavage, while ctDNA fragments range between 90 and 150 bp, and others between 250 and 320 bp [13]. The proportion of ctDNA in cfDNA varies, and the most used methods to detect cfDNA are real-time quantitative polymerase chain reaction (qRT-PCR) and next-generation sequencing (NGS) [14,15].

Liquid biopsies, by quantification of cfDNA, can be used for all types of lymphomas because the plasma from peripheral blood $(\mathrm{PB})$ regularly contains low levels of detectable lymphoma-derived ctDNA, as well as in myeloid pathology (AML, MDS, and MPN) or other lymphoid pathology (MM and ALL) [16]. Therefore, ctDNA-based liquid biopsy has emerged as a platform to genotype these tumors.

\subsubsection{RNA in liquid biopsy}

MicroRNAs (miRNAs) are a class of small molecules of 19-24 nucleotides in length, and they are the most abundant RNA molecules in the blood; they can be carried in the 
exosomes or TEPs. They have high stability and play an important role in tumor growth and treatment resistance [17].

\subsubsection{Tumor-educated platelets (TEP)}

Platelets are circulating anucleated fragments originating from megakaryocytes in bone marrow, and they participate in hemostasis and initiation of wound healing, but they also have a role in systemic and local responses to tumor growth, as tumor cells alter the RNA profile of these platelets. In addition, TEPs can ingest circulating mRNA released by tumor cells or solubilized tumor-associated proteins [18]. These interactions may signify a potential for cancer diagnosis or monitoring [19].

\subsubsection{Exosomes}

Exosomes are a type of extracellular vesicle of endocytic origin, ranging in size between 30 and $100 \mathrm{~nm}$; they are detectable in the blood of patients with some types of cancer, and they carry proteins and nucleic acids. They are analyzed through the RNA content [20]. For example, the ability of HL-specific exosomal microRNAs (miRNAs) to inform treatment response in HL has been studied. The authors found that the specificity and sensitivity of exosomal miRNAs are superior to protein-bound miRNAs with regard to HL detection [21].

\subsection{Common techniques in DNA liquid biopsies}

The first methods used to analyze ctDNA were based on PCR, using technologies such as TaqMan, PNA clamps, and Scorpion Amplification Refractory Mutation System; however, they were limited because of their analytical sensitivity and specificity [22]. However, in the last decade, other newer techniques have been used: Digital PCR (dPCR) and NGS have emerged, increasing the detection thresholds up to $0.01 \%$ for mutant allele abundance [23].

dPCR-based methods have a high sensitivity (0.01\%) (better than real-time quantitative PCR), but can detect few alterations simultaneously, and they must be optimized for each mutation [24].

NGS-based methods can detect multiple alterations simultaneously. Initially, they had insufficient sensitivity $(>1 \%)$, but various groups have been developing methods that allow greater sensitivity; some of them have tried to use deep sequencing of a limited number of amplicons for commonly mutated genes in cancer. The technique, called CAncer Personalized Profiling by deep Sequencing (CAPP-Seq), can detect all major classes of mutations (single nucleotide variants, indels, rearrangements, and copy number alterations). Capture-based NGS methods enrich genomic regions before sequencing by a hybridization of target regions to antisense oligonucleotides; with this technique, large portions of the genome can be examined [25].

\subsection{Minimal residual disease using liquid biopsy}

Minimal/measurable residual disease (MRD) is defined as the persistence of a small number of malignant cells after initial treatment, undetectable by morphologic or conventional screening methods. Tables 1 and 2 detail the methods used in clinical practice to evaluate the response to treatment in different hematological malignancies.

In myeloid pathology, MRD-guided approaches have become an attractive therapeutic strategy (e.g., CML, AML, and MDS), allowing a more individualized therapy, possibly leading to less treatment-related toxicities and better outcomes. Moreover, treatment upon molecular relapse is more effective than upon hematologic relapse (e.g., after allogeneic HCT in AML and MDS) [26]. Monitoring of the clonal evolution of AML identifies the leukemia subtype, clinical outcome, and potential new drug targets for post-remission strategies or relapse $[27,28]$. However, a universal MRD marker for MDS and AML is unlikely because of the genotypic and phenotypic heterogeneity of these diseases [29]. Thus, 
a more effective strategy may be individualized MRD monitoring using a targeted nextgeneration sequencing panel [30].

In lymphoid pathology, MRD-guided approaches, mainly based on the monitoring of clonal rearrangements of Igs or TCR, have also become a therapeutic strategy for ALL and MM. However, the available MRD strategies have not yet been incorporated into the assistance practice for other lymphoid tumors, where imaging methods are the method of choice to assess response to treatment.

Liquid biopsies have several advantages over bone marrow for the detection of MRD: They are less invasive, may provide a more comprehensive molecular overview of tumor heterogeneity, and make it easier to obtain repeated blood samples over time to understand the dynamics of the response to a specific treatment. Multiple studies have demonstrated a satisfactory positive predictive value of ctDNA detection, as the presence of MRD identified through ctDNA is associated with worse disease-free survival (DFS). Nevertheless, several hurdles maintain the negative predictive value of the technique at a low level: Detection methods are not sensitive enough to detect ctDNA at very low amounts, new clones not captured by the selected technique can emerge, and the timing of post-treatment sampling can be inappropriate [31]. Moreover, in the case of cfDNA, the logistics of sample processing are crucial to avoid white blood cell (WBC) lysis and subsequent genomic DNA contamination. To avoid this issue, samples shall be processed in less than four hours or collected in tubes with a cell stabilizer [32].

Table 1. Minimal residual disease monitoring methods in myeloid malignancies.

\begin{tabular}{|c|c|c|c|c|c|}
\hline Method & APL & AML & MDS & MPN & CML \\
\hline Image methods & No & No & No & Yes & No \\
\hline $\begin{array}{c}\text { CT or PET/CT } \\
\text { MRI }\end{array}$ & & & & $\begin{array}{c}\text { Spleen measurement } \\
\text { by CT or MRI (clinical } \\
\text { trials) }\end{array}$ & \\
\hline $\begin{array}{l}\text { Histologic/morphologic } \\
\text { methods }\end{array}$ & $\begin{array}{c}\text { Yes, } \mathrm{BM} \text { or } \mathrm{PB}, \\
10^{-2}\end{array}$ & Yes, BM, $10^{-2}$ & Yes, BM, $10^{-2}$ & $\begin{array}{c}\text { Yes, BM, } 10^{-2} \text { (Clinical } \\
\text { Trials) }\end{array}$ & No \\
\hline MFC methods & No & $\begin{array}{c}\text { Yes, BM, } \\
10^{-4} \text { or } 10^{-5}\end{array}$ & $\begin{array}{c}\text { Yes, BM, } \\
10^{-4} \text { or } 10^{-5}\end{array}$ & No recommendations & No \\
\hline Molecular methods & $\begin{array}{c}\text { Yes, RQ-PCR } \\
(P M L / R A R A), \\
\text { BM, } 10^{-5}\end{array}$ & $\begin{array}{c}\text { RQ-PCR *, BM or } \\
\text { PB, } \\
10^{-6}\end{array}$ & No recommendations & No recommendations & $\begin{array}{c}\text { Yes, PB }(B C R / A B L 1), \\
10^{-5}\end{array}$ \\
\hline NGS methods & No & $\mathrm{NGS}^{* *}, \mathrm{BM}, 10^{-6}$ & $\begin{array}{l}\text { Investigational use } \\
\text { (clinical trials) }\end{array}$ & $\begin{array}{l}\text { Investigational use } \\
\text { (clinical trials) }\end{array}$ & No \\
\hline Timing of MRD assessment & $\begin{array}{l}\text { Post-induction } \\
\text { time and PCR } \\
\text { every } 3 \mathrm{~m} \text { for } 2 \\
\text { years }\end{array}$ & $\begin{array}{l}\text { Upon completion of } \\
\text { the initial induction, } \\
\text { additional time } \\
\text { points should be } \\
\text { guided by the } \\
\text { regimen used before } \\
\text { allogeneic } \\
\text { trasplantation }\end{array}$ & No recommendations & Only in clinical trials & $\begin{array}{c}\text { PCR every } 3 \mathrm{~m} \text { for } \\
\text { one year, then every } \\
6 \mathrm{~m} .\end{array}$ \\
\hline References & {$[33,34]$} & [34] & [35] & [36-38] & [39] \\
\hline
\end{tabular}

APL, acute promyelocytic leukemia; AML, acute myeloid leukemia; MDS, myelodysplastic syndrome; MPS, myeloproliferative syndrome; $\mathrm{CML}$, chronic myeloid leukemia; CT, computed tomography; PET, positron emission tomography; MRI, magnetic resonance imaging; $\mathrm{CR}$, complete response; $\mathrm{y}$, year; $\mathrm{BM}$, bone marrow; $\mathrm{PB}$, peripheral blood; FISH, fluorescence in situ hybridization; MFC, multiparametric flow cytometry; RQ-PCR, real quantitative PCR; ASO-PCR, allelic specific oligonucleotide PCR; NGS, next-generation sequencing; MRD, minimal residual disease; $\mathrm{m}$, month. The information in the boxes includes the test used, the sample to be studied, and the sensitivity of the method. * CBFb-MYH11, RUNX1-RUNX1T1, and mutNPM1. ** 
Excluded DTA mutations. *** 2013 IWG-MRT and ELN guidelines recommend monitoring the response (anemia response, spleen response, and symptom response), signs and symptoms of disease progression every three to six months during the course of treatment. BM should be performed as clinically indicated.

Table 2. Minimal residual disease monitoring methods in lymphoid malignancies.

\begin{tabular}{|c|c|c|c|c|c|c|}
\hline Method & ALL & DLBCL & FL & HL & CLL & MM \\
\hline Image methods & No & Yes & Yes & Yes & Yes & Yes \\
\hline $\begin{array}{c}\text { CT or PET/CT } \\
\text { MRI }\end{array}$ & & $\begin{array}{c}\text { PET-TAC scan or } \\
\text { CT scan con } \\
\text { contrast }\end{array}$ & $\begin{array}{c}\text { PET-TAC scan or } \\
\text { CT scan con } \\
\text { contrast }\end{array}$ & $\begin{array}{c}\text { CR include PET } \\
\text { negative within } 3 \\
\text { m posttreatment } \\
\text { Consider body } \\
\text { CT with contrast } \\
\text { no more often } \\
\text { than every } 6 \mathrm{~m} \\
\text { For the first } 2 \mathrm{y} \\
\text { following } \\
\text { completion of } \\
\text { therapy }\end{array}$ & $\begin{array}{l}\text { Lymphoid } \\
\text { nodes, } \\
\text { spleen, and } \\
\text { liver } \\
\text { evaluation by } \\
\text { CT }\end{array}$ & $\mathrm{PET} / \mathrm{CT}$ \\
\hline $\begin{array}{l}\text { Histologic/morphologic } \\
\text { methods }\end{array}$ & Yes, BM, $10^{-2}$ & $\begin{array}{l}\text { BM biopsy } \\
\text { (optional) }\end{array}$ & $\begin{array}{l}\text { BM biopsy } \\
\text { (optional) }\end{array}$ & $\begin{array}{c}\text { No, unless there } \\
\text { is BM } \\
\text { involvement at } \\
\text { diagnosis }\end{array}$ & Yes, BM, 10-2 & $\begin{array}{l}\text { Yes, BM with FISH, } \\
10^{-2}\end{array}$ \\
\hline MFC methods & Yes, BM, $10^{-4}$ & No & No & No & $\begin{array}{c}\text { Yes, BM or } \\
\text { PB, } 10^{-5}\end{array}$ & Yes, BM, 10-5 \\
\hline Molecular methods & $\begin{array}{c}\text { RQ-PCR, BM, } \\
10^{-6}\end{array}$ & No & No & No & $\begin{array}{c}\text { ASO-PCR, } \\
\text { BM or PB, 10- } \\
4\end{array}$ & No \\
\hline NGS methods & $\begin{array}{l}\text { NGS Igs-TCR, } \\
\text { BM, } 10^{-6}\end{array}$ & $\begin{array}{c}\text { NGS liquid } \\
\text { biopsy, } \\
\text { investigational } \\
\text { use } \\
\end{array}$ & $\begin{array}{c}\text { NGS liquid } \\
\text { biopsy, } \\
\text { investigational } \\
\text { use } \\
\end{array}$ & $\begin{array}{l}\text { Investigational } \\
\text { use }\end{array}$ & $\begin{array}{l}\text { NGS Igs, BM } \\
\text { or } \mathrm{PB}, 10^{-6}\end{array}$ & NGS Igs, BM, 10-6 \\
\hline $\begin{array}{l}\text { Timing of MRD } \\
\text { assessment }\end{array}$ & $\begin{array}{c}\text { Upon } \\
\text { completion of } \\
\text { initial } \\
\text { induction and } \\
\text { additional } \\
\text { time points } \\
\text { should be } \\
\text { guided by the } \\
\text { regimen used }\end{array}$ & $\begin{array}{l}\text { Post-third cycle } \\
\text { and every } 3 \mathrm{~m}\end{array}$ & $\begin{array}{c}\text { Post-third cycle } \\
\text { Every } 3-6 \mathrm{~m} \text { for } 5 \\
\text { years }\end{array}$ & $\begin{array}{l}\text { Post-third cycle } \\
\text { Additional time } \\
\text { points should be } \\
\text { guided by the } \\
\text { regimen used }\end{array}$ & $\begin{array}{l}\text { Post-third } \\
\text { cycle } \\
\text { Every 3-6 m } \\
\text { for } 5 \text { years }\end{array}$ & $\begin{array}{l}\text { Post-third cycle } \\
\text { Consider body CT } \\
\text { with contrast no } \\
\text { more often than } \\
\text { every } 6 \mathrm{~m} \text { For the } \\
\text { first } 2 \mathrm{y} \text { following } \\
\text { completion of } \\
\text { therapy }\end{array}$ \\
\hline References & [40] & [41] & [41] & [42] & [43] & {$[44]$} \\
\hline
\end{tabular}

ALL, acute lymphoblastic leukemia; DLBCL, diffuse large B cell lymphoma; FL, follicular lymphoma; HL, Hodgkin lymphoma; CLL, chronic lymphatic leukemia; MM, multiple myeloma; CT, computed tomography; PET, positron emission tomography; MRI, magnetic resonance imaging; CR, complete response; y, year; BM, bone marrow; PB, peripheral blood; FISH, fluorescence in situ hybridization; MFC, multiparametric flow cytometry; RQ-PCR, real quantitative PCR; ASO-PCR, allelic specific oligonucleotide PCR; NGS, next-generation sequencing; MRD, minimal residual disease; $\mathrm{m}$, month; y; year. The information in the boxes includes the test used, the sample to be studied, and the sensitivity of the method. 


\section{Myeloid malignancies}

\subsection{Acute myeloid leukemia (Table 3)}

Acute myeloid leukemia (AML) is a malignancy of hematopoietic stem cell precursors of the myeloid lineage, causing an overproduction of neoplastic clonal myeloid stem cells and infiltration of extramedullary organs [45-49]. A correct diagnosis and classification of the disease are critical for the treatment of patients with AML, and an evaluation of the response to treatment by MRD quantification is essential to optimize treatment and select the appropriate method of response consolidation. Quantification of MRD is very important because it can identify those patients at high risk of relapse. Currently, studies including morphologic evaluation on bone marrow (BM) aspirate or biopsy, cytogenetic analysis and molecular testing using gene panels or NGS are currently being carried out for diagnosis and follow-up [50]. Nevertheless, several studies have explored the use of peripheral blood (PB) as input for the detection of residual disease, and MRD obtained of PB is already being incorporated into AML protocols for clinical decision making (e.g., CBF and NPM1 AML Pethema protocols with MRD by RT-qPCR for follow-up RUNX1RUNX1T1, CBFb-MYH11, and NPM1 mutations) [51-53]. Maurillo et al. analyzed BM and PB samples in 50 AML patients, 48 of whom were re-evaluated after consolidation. The preliminary results showed concordance in CTC quantification between PB and BM samples, increasing the disease stratification value and improving MRD monitoring in AML patients. Analysis of MRD after consolidation revealed useful prognostic information [54].

MRD in AML is defined as the presence of leukemic blasts at a level lower than the limit of conventional morphologic detection (1:1000-1:106 white blood cells) [55]. The main techniques used thus far for MRD in AML patients are multiparameter flow cytometry (MFC) and molecular techniques using RT-qPCR. The detection of MRD by MFC uses the leukemia-associated immunophenotypes (LAIPs) approach (LAIPs are defined at diagnosis and their presence is subsequently monitored at follow-up) and the DfN approach (DfN, different-from normal, irrespective of LAIP at diagnosis) and is applicable in most AML patients with a sensitivity reported from $10^{-3}$ to $10^{-5}$. Molecular MRD is more sensitive and specific than flow cytometry, and real-time quantitative PCR (RT-qPCR) can achieve a sensitivity of 10-4-10-6 [56-60], droplet digital PCR (ddPCR) can reach a sensitivity of $10^{-4}-10^{-6}$ as well $[58,61]$, and NGS can achieve a sensitivity of $10^{-4}-10^{-5}[27,62,63]$. RT-qPCR has a problem in that that its applicability is limited to $30 \%-40 \%$ of AMLs. NGS has an acceptable sensitivity but with better applicability than RT-qPCR (>85\% of AML cases) and provides new insights into the evolution of subclones that emerge under treatment or during disease progression. This allows the availability of markers that can be used to measure MRD to be expanded [64-66].

Advances in NGS technology have also enabled the sequencing of increasingly low amounts of DNA using a variety of sources [67]. Blood contains many types of biological materials, such as circulating cell, mRNA, proteins, or cfDNA. In the blood of patients with AML, a part of the ctDNA is released by the tumor [68], but in the peripheral blood of these AML patients circulate the tumor cells themselves, called blastic cells. This CTC quantification has been incorporated to protocols, as previously cited.

However, there is not much reported experience with cfDNA in AML patients. Through new technologies, the number of studies carried out in this field is increasing. Short et al. analyzed cfDNA and BM samples in 22 AML patients. They analyzed 28 genes and found that five mutations were detected only in cfDNA, 15 were detected in the BM, and 19 were detected in both samples. Generally, those mutations detected in only one source had a VAF of less than $10 \%$. This suggests that both methods could miss subclonal populations. In addition, the cfDNA samples detected new or persistent mutations that 
implied relapse. The results suggest that cfDNA and BM are complementary in the followup and monitoring of disease in these patients [69].

Nakamura et al. conducted a study in 51 patients (37 with AML and 14 with MDS) to investigate the role of ctDNA in the risk of relapse after undergoing myeloablative allogeneic hematopoietic stem cell transplantation (alloSCT), with a median follow-up of 32 months post-alloSCT, where 16 of 51 patients relapsed at a median of seven months. They collected ctDNA and BM samples at diagnosis and follow-up. NGS studies with a 54- or 141-gene panel or WES were carried out. They were able to observe an increase in ctDNA in relapsed patients, determining that non-invasive testing has comparable utility in the BM testing, predicting the risk of relapse [70]. In this work, DTA gene mutations were prognostic factors of leukemia relapse.

Rausch et al. demonstrated the application of a new method called double drop-off digital droplet PCR (DDO-ddPCR) for the detection of gene mutations in NPM1, IDH2, and NRAS, which can detect and quantify diverse alterations at two nearby hotspot regions present in these genes; they used this method for disease monitoring and compared to qPCR, ddPCR, and NGS. At 38 time points (78\%), the results of cfDNA-ddPCR and BM qPCR were concordant, whereas at 11 time points (22\%) during follow-up, an NPM1 mutation was detected in the BM but not in the PB cfDNA. cfDNA analysis was found to have a similar sensitivity compared to quantitative PCR-based analysis of peripheral blood but lower sensitivity compared to BM qPCR [71].

In conclusion, the use of liquid biopsies in AML shows promising results in terms of disease staging, monitoring, prognosis, and treatment [72], as well as in the detection of early relapse [73]. Although CTCs and cfDNA have been shown to be new biomarkers in the blood [25], at the moment, these cannot yet replace BM studies, mainly due to the low concentration of cfDNA in the blood [72]. An additional obstacle in current molecular MRD approaches, and that also affects liquid biopsy studies, is to find the molecular variants that represent and are specific to leukemic cells with the capability of relapsing [74]. The determination of MRD is complicated by the fact that many treated patients have persistent clonal hematopoiesis $(\mathrm{CH})$ that may not reflect residual AML [75]. For this, the ELN group in the consensus document for MRD in AML 2021 provided the following recommendations: Considering all detected mutations as potential MRD markers; germline mutations (VAF of $50 \%$ in genes ANKRD26, CEBPA, DDX41, ETV6, GATA2, RUNX1, and TP53) should be excluded as NGS-MRD markers, as they are non-informative for MRD; DTA mutations can be found in age-related clonal hematopoiesis and should be excluded from MRD analysis, as mutations associated with clonal hematopoiesis often persist during remission and thus may not represent the leukemic clone. If the only detectable mutations are in DTA genes, it is recommended to use MFC and/or PCR for MRD assessment; mutations in signaling pathway genes (e.g., FLT3-ITD, FLT3-TKD, $K I T, K R A S$, and NRAS) likely represent residual AML when detected, but are often subclonal and have a low negative predictive value. These mutations are best used in combination with additional MRD markers; NGS-MRD analysis in patients treated with targeted agents (FLT3 and IDH1/IDH2 inhibitors) should include the molecular marker that is targeted, but also others that are present in the sample [33].

Table 3. Liquid biopsies in acute myeloid leukemia. 


\begin{tabular}{|c|c|c|c|c|c|}
\hline & Methods & $\begin{array}{c}\text { Cohort size/disease } \\
\text { stage }\end{array}$ & Evidence: Key points & Application & Ref. \\
\hline $\begin{array}{c}\text { IDH1 and IDH2 genes } \\
\text { (R140 and R172 } \\
\text { mutations) }\end{array}$ & $\begin{array}{c}\text { Sanger, } \\
\text { ddPCR, NGS, } \\
\text { and qPCR }\end{array}$ & $\begin{array}{c}n=60 \\
\text { Diagnosis }\end{array}$ & $\begin{array}{l}\text { Give evidence that the drop-off } \\
\text { ddPCR is a valid new molecular tool for de- } \\
\text { tecting IDH2 mutations } \\
\text { Techniques such as ddPCR, NGS, and } \\
\text { qPCR started to be implemented }\end{array}$ & MRD & {$[53]$} \\
\hline $\begin{array}{c}C E B P A \text { mutations and } \\
\text { blast cells }\end{array}$ & RT-qPCR & $\begin{array}{c}n=4(n=3 \\
\text { diagnostic, } n=1 \\
\text { relapse })\end{array}$ & $\begin{array}{l}\text { - } \quad \text { RT-qPCR can achieve a sensitivity of } \\
10^{-4}-10^{-6} \\
\text { Describe specific RT-qPCR for CEBPA } \\
\text { mutations } \\
\end{array}$ & Concordance & {$[56]$} \\
\hline NPM1 mutations & $\begin{array}{c}\text { Flow } \\
\text { cytometry, } \\
\text { RT-qPCR }\end{array}$ & $\begin{array}{c}n=15 \text { patients } \\
n=45 \text { MRD samples } \\
\text { Diagnosis and } \\
\text { follow-up }\end{array}$ & $\begin{array}{l}\text { Knowledge of RT-qPCR-based MRD } \\
\text { results } \\
\text { RT-qPCR has a higher sensitivity than } \\
\text { FC }\left(10^{-4}-10^{-6} \text { vs. } 10^{-3}-10^{-5}\right) \\
\end{array}$ & MRD & {$[51]$} \\
\hline Somatic mutations & $\begin{array}{c}\text { ddPCR, RT- } \\
\text { qPCR }\end{array}$ & $\begin{array}{c}n=41 \text { patients with } \\
\text { AML-M1/M2 } \\
n=20 \text { healthy } \\
\text { volunteers }\end{array}$ & $\begin{array}{l}\text { - } \quad \text { ddPCR can achieve a sensitivity of } 10^{-} \\
\text {- } \quad \text { Identify genes that contribute to leu- } \\
\text { kemogenesis } \\
\end{array}$ & Concordance & {$[52]$} \\
\hline Residual leukemic cells & $\begin{array}{l}\text { Flow } \\
\text { cytometry }\end{array}$ & $\begin{array}{c}n=135 \text { patients with } \\
\text { de novo AML (100 } \\
\text { achieving CR after } \\
\text { intensive } \\
\text { chemotherapy) }\end{array}$ & $\begin{array}{l}\text { - Flow cytometry achieve a sensitivity } \\
\text { of } 10^{-4} \\
\begin{array}{l}\text { - MRD patients have a five-year RFS } \\
\text { - } \quad \text { MRD }\end{array} \\
\text { nosis } \\
\text { Incorporate MRD assessment in the } \\
\text { protocols for the treatment of AML }\end{array}$ & $\begin{array}{c}\text { MRD } \\
\text { Response } \\
\text { assessment }\end{array}$ & {$[55]$} \\
\hline Somatic mutation & NGS & $\begin{array}{c}n=22 \text { (after } \\
\text { remission) } \\
\text { post-treatment }\end{array}$ & $\begin{array}{l}\text { - cfDNA and BM were complementary } \\
\text { in the follow-up and monitoring of disease } \\
\text { - The concordance of VAF assessment } \\
\text { by both methods was high }\left(R^{2}=0.849\right)\end{array}$ & $\begin{array}{l}\text { Concordance } \\
\text { MRD }\end{array}$ & [69] \\
\hline Driver mutations & $\begin{array}{l}\text { NGS } \\
\text { dPCR }\end{array}$ & $\begin{array}{c}n=53(n=37 \text { AML } \\
n=14 \text { MDS })(\text { after } \\
\text { post-allo SCT) } \\
\text { Diagnosis and post- } \\
\text { treatment }\end{array}$ & $\begin{array}{l}\text { - } \quad \text { An increase in ctDNA in relapsed pa- } \\
\text { tients } \\
\text { ctDNA has concordance with BM test- } \\
\text { ing, having a comparable utility }\end{array}$ & $\begin{array}{l}\text { Concordance } \\
\text { MRD } \\
\text { Response } \\
\text { assessment }\end{array}$ & {$[70]$} \\
\hline Somatic mutation & $\begin{array}{l}\text { DDO-ddPCR } \\
\text { dPCR } \\
\text { qPCR } \\
\text { NGS }\end{array}$ & $\begin{array}{c}n=57 \text { samples } \\
(\text { cfDNA), } n=28 \\
(\mathrm{PB}), n=53(\mathrm{BM}) \\
\text { Post-treatment }\end{array}$ & 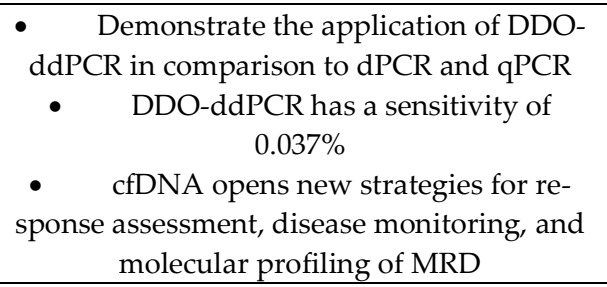 & $\begin{array}{l}\text { Concordance } \\
\text { MRD }\end{array}$ & {$[71]$} \\
\hline Leukemic cells & $\begin{array}{c}\text { Flow } \\
\text { cytometry }\end{array}$ & $\begin{array}{c}n=50 \text { patients with } \\
\text { de novo AML }\end{array}$ & $\begin{array}{l}\text { - } \mathrm{BM} \text { and PB samples were significantly } \\
\text { concordant }(r=0.86 \text { and } 0.82 \text {, respectively, } p \\
<0.001) \text {. } \\
\text { - The cut-off value of residual leukemic } \\
\text { cells was } 1.5 \times 10^{-4} \\
\text { PB MRD was found to have a signifi- } \\
\text { cant effect on relapse-free survival ( } p= \\
0.036) \text {. }\end{array}$ & $\begin{array}{l}\text { Concordance } \\
\text { MRD }\end{array}$ & {$[54]$} \\
\hline $\begin{array}{c}\text { Primitive blast } \\
\text { (CD34+/CD117+/CD133 } \\
+)\end{array}$ & $\begin{array}{c}\text { Flow } \\
\text { cytometry }\end{array}$ & $\begin{array}{c}n=114 \text { patients (205 } \\
\text { paired BM and PB } \\
\text { samples) } \\
\text { Diagnosis and post- } \\
\text { treatment }\end{array}$ & $\begin{array}{l}\text { - Primitive blast frequency was lower } \\
\text { in the PB; PB MRD is more specific than BM } \\
\text { - The role of MRD in the PB may have } \\
\text { an essential use in the future clinical man- } \\
\text { agement of AML patients } \\
\text { Flow cytometry has a sensitivity of } 10^{-} \\
3_{-}-10^{-5}\end{array}$ & $\begin{array}{c}\text { Concordance } \\
\text { MRD } \\
\text { Response } \\
\text { assessment }\end{array}$ & [59] \\
\hline
\end{tabular}


Ref., reference; ddPCR, droplet digital PCR; NGS, next-generation sequencing; qPCR, quantitative PCR; MRD, minimal residual disease; RT-qPCR, real-time quantitative PCR; FC, flow cytometry; CR, complete response; RFS, relapse-free survival; $\mathrm{dPCR}$, digital PCR; $\mathrm{BM}$, bone marrow; AML, acute myeloid leukemia; MDS, myelodysplastic syndrome; SCT, stem cell transplantation; VAF, variant allele frequency; DDO-ddPCR, D-aspartate oxidase ddPCR, droplet digital PCR; PB, peripheral blood; cfDNA, cell-free DNA.

\subsection{Myelodisplastic syndromes (Table 4)}

Myelodysplastic syndromes are a heterogeneous group of hemopathies characterized by a clonal disorder of hematopoietic stem cells and whose main problems are caused by the morbidities associated with cytopenias and by the potential risk of progression to acute myeloid leukemia. It is a disease typical of older patients and in most cases, it is not possible to opt for treatments with curative options, so it is not a pathology in which MRD techniques have been developed as in others (e.g., AML). However, in recent years, several papers have been published highlighting the usefulness of cfDNA monitoring in patients with MDS.

Dawson published a work where the detection of mutations and cytogenetic alterations in cfDNA predicts treatment failure. Targeted deep sequencing (TS) was performed on DNA derived from BM and plasma using a customized panel of 55 genes. Sequencing of the BM samples identified putative driver mutations in 10 of 12 patients. Digital polymerase chain reaction (dPCR) was performed to validate the TS results. Quantification of the mutant allele fraction (MAF) showed excellent correlation between TS and dPCR. Through analysis of serial bone marrow and matched plasma samples $(n=75)$, the authors demonstrated that ctDNA is directly comparable to bone marrow biopsies in representing the genomic heterogeneity of malignant clones in MDS, and serial monitoring of ctDNA allows concurrent tracking of mutations throughout therapy and could be able to anticipate treatment failure. In addition, in the times points with severe neutropenia, allelic burden by variant allele frequency (VAF) determination was higher in the plasma cfDNA than leucocyte BM [76].

Nakamura published the prognostic impact of circulating tumor DNA status postallogeneic hematopoietic stem cell transplantation in AML and MDS. Fifty-three patients with MDS/AML were studied by targeted 37-gene panel NGS at diagnosis and detected 51 cases $(96.2 \%)$ with driver mutations at diagnosis by NGS with a limit of detection of $0.04 \%$. The follow-up was made by ddPCR in serum samples with one or more markers with a limit of detection of $0.1 \%-0.01 \%$. They found that ctDNA reflects clonal dynamics, and the persistent molecular MRD status post-allogeneic stem cell transplantation (SCT) predicts relapse and survival. Increased ctDNA levels between month 1 and month 3 postallogeneic could be a predictor of relapse. The use of serum ctDNA has a benefit over leukocyte DNA in predicting relapse, with concordance observed in 8/11 cases; however, in cases with cytopenias, it was only detectable in serum ctDNA [70].

In another study, the peripheral plasma cfDNA samples available from patients with aplastic anemia (AA; $n=25)$, MDS $(n=27)$, and a healthy cohort $(n=107)$ were screened for somatic variants in genes related to hematologic malignancies by targeted-panel NGS. The results were further compared to DNA sequencing of matched blood cells. The authors observed that the concordance between cfDNA and blood cells was poor for clonal hematopoiesis $(\mathrm{CH})$ detection when variants were at variant allele frequency $<10 \%$, which was mostly observed in the healthy and AA cohort, but not in the MDS group. The use of cfDNA does not offer advantages over CTC for the detection of variants associated with clonal hematopoiesis in diseases with low allele burdens and healthy individuals. They detected numerous new variants with a low number of reads in cfDNA that they considered artifacts, so they recommended strict filtering criteria in these cases. Ultra-sensitive assays with robust sequencing coverage and error-correction methodology may be required to overcome assay discordance [77]. 
Table 4. Liquid biopsies in myelodysplastic syndromes.

\begin{tabular}{|c|c|c|c|c|c|}
\hline Target & Methods & $\begin{array}{c}\text { Cohort size/disease } \\
\text { stage }\end{array}$ & Evidences: key points & Application & Ref. \\
\hline $\begin{array}{l}\text { Somatic } \\
\text { mutations }\end{array}$ & $\begin{array}{c}\text { NGS } \\
\text { (55 genes) }\end{array}$ & $\begin{array}{c}n=12 \text { patients } \\
75 \text { samples of } \\
\text { follow-up }\end{array}$ & $\begin{array}{l}\text { - } \mathrm{ctDNA} \text { is directly comparable to BM biopsy in } \\
\text { representing the genomic heterogeneity of malignant } \\
\text { clones in MDS } \\
\text { - Serial monitoring of ctDNA allows concurrent } \\
\text { tracking of mutations and could be able to anticipate } \\
\text { treatment failure }\end{array}$ & $\begin{array}{c}\text { MRD } \\
\text { Concordance }\end{array}$ & {$[76]$} \\
\hline $\begin{array}{l}\text { Somatic } \\
\text { mutations }\end{array}$ & $\begin{array}{c}\text { NGS } \\
\text { diagnostic } \\
\text { (37 genes) } \\
\text { ddPCR for } \\
\text { follow-up }\end{array}$ & $\begin{array}{c}n=51(n=15 \text { novo } \\
\text { AML, } n=22 \\
\text { secondary AML, } n= \\
\quad 14 \text { MDS }) \\
\text { LOD }(\mathrm{NGS})=0.04 \% \\
\text { LOD }(\mathrm{ddPCR})= \\
0.1 \%-0.01 \%\end{array}$ & $\begin{array}{l}\text { ctDNA reflects clonal dynamics, and persistent } \\
\text { molecular MRD post-alloSCT predicts relapse and } \\
\text { survival with usefulness of DTA mutations } \\
\text { Relevance of ctDNA over bulk PB analysis, es- } \\
\text { pecially when there are cytopenias }\end{array}$ & $\begin{array}{l}\text { Concordance } \\
\text { MRD }\end{array}$ & [70] \\
\hline $\begin{array}{c}\text { Somatic } \\
\text { mutations } \\
\text { (CHIP } \\
\text { quantification) }\end{array}$ & $\begin{array}{c}\text { NGS } \\
\text { (200 genes) }\end{array}$ & $\begin{array}{c}n=25 \text { AA patients, } \\
n=27 \text { MDS } \\
\text { patients, } n=107 \\
\text { healthy controls } \\
\text { LOD }=0.96 \%\end{array}$ & $\begin{array}{l}\text { The concordance between cfDNA and blood } \\
\text { cells was poor for clonal hematopoiesis detection } \\
\text { when variants were at VAF }<10 \% \text {, and stringent crite- } \\
\text { ria to filter out discordant variants improved cfDNA } \\
\text { concordance with blood cells } \\
\text { Quantification of CHIP in cfDNA was not } \\
\text { comparable to blood cells }\end{array}$ & Concordance & [77] \\
\hline
\end{tabular}

Ref., reference; NGS, next-generation sequencing; ctDNA, circulant tumor DNA; BM, bone marrow; MRD, minimal residual disease; ddPCR, droplet digital PCR; AML, acute myeloid leukemia; MDS, myelodysplastic syndrome; LOD, limit of detection; AlloSCT, allogeneic stem cell transplantation; PB, peripheral blood; CHIP, clonal hematopoiesis of indeterminate potential; AA, aplastic anemia; cfDNA, cell-free DNA.

\subsection{Myeloproliferative neoplasms (Table 5)}

Myeloproliferative neoplasms are disorders characterized by stem cell-derived clonal myeloproliferation with mutually exclusive $J A K 2, C A L R$, and MPL mutations as phenotype-driver variants [78,79]. In myeloproliferative neoplasms, the aim of the available treatments is to avoid thrombosis and not good treatments that decrease the disease burden or cure the disease are available, with the exception of allogeneic transplantation in advanced stage primary myelofibrosis (PMF). To date, drug therapy has not been shown to improve survival or prevent leukemic/fibrotic transformation in either essential thrombocythemia (ET) or polycythemia vera (PV); therefore, treatment is primarily directed at preventing thrombotic complications [80].

Based on these assumptions, the usefulness of markers to quantify residual disease is unclear. However, Bellosillo et al. published a work where 107 patients with MPNs were studied by NGS and ddPCR: 33 PV, 56 ET, 14 PMF, and four unclassifiable MPNs (uMPNs). The aim of the study was to assess the accuracy and reliability of cfDNA analysis in a cohort of MPN patients, comparing this technique to the genotype of peripheral blood granulocytes. The authors showed that the amount of cfDNA in plasma varies among MPN disease phenotypes. A significant positive correlation was observed between the amount of cfDNA and PMF (vs. PV), leukocyte count, LDH, MPL-mutated group, and suffering from a thrombotic event at the time of diagnosis or during follow-up. In addition, cfDNA and granulocyte DNA showed an equivalent mutational profile and the discrepancies were detected with variants at low VAF. MPL-mutated and ASLX1-mutated patients had higher amounts of cfDNA. However, in relation to the role of cfDNA as a monitoring response to treatment, for the PV case, who received hydroxycarbamide, the $J A K 2 V 617 F$ VAF remained stable in both the granulocytes and cfDNA during the followup. For the ET case, who was treated with interferon, a proportional decrease in the JAK2V617F VAF was observed in granulocytes and cfDNA [81]. 
Table 5. Liquid biopsies in myeloproliferative neoplasms.

\begin{tabular}{|c|c|c|c|c|c|}
\hline Target & Methods & $\begin{array}{c}\text { Cohort size/disease } \\
\text { stage }\end{array}$ & Evidences: Key points & Application & Ref. \\
\hline $\begin{array}{l}\text { Somatic } \\
\text { mutations }\end{array}$ & $\begin{array}{c}\text { NGS } \\
\text { ddPCR }\end{array}$ & $\begin{array}{c}n=107 \text { patients (33 } \\
\text { PV, } 56 \text { ET, } 14 \text { PMF, } \\
\text { and } 4 \text { uMPNs) }\end{array}$ & $\begin{array}{l}\text { A significant concordance was observed be- } \\
\text { tween the amount of cfDNA and PMF (vs. PV), leu- } \\
\text { kocyte count, LDH, MPL-mutated group, and suffer- } \\
\text { ing from a thrombotic event at the time of diagnosis } \\
\text { or during follow-up } \\
\text { For ET cases treated with IFN, a proportional } \\
\text { decrease in the JAKV617F VAF was observed in gran- } \\
\text { ulocytes and cfDNA }\end{array}$ & $\begin{array}{l}\text { Concordance } \\
\text { Response } \\
\text { assessment }\end{array}$ & {$[81]$} \\
\hline
\end{tabular}

Ref., reference; NGS, next-generation sequencing; ddPCR, digital droplet PCR; PV, polycythemia vera; ET, essential thrombocythemia; PMF, primary myelofibrosis; uMPNs, unclassifiable myeloproliferative neoplasms; cfDNA, cell-free DNA; LDH, lactate dehydrogenase; IFN, interferon; $\mathrm{VAF}$, variant allele frequency.

\section{Lymphoid malignancies}

\section{1/ Acute lymphoblastic leukemia (Table 6)}

Acute lymphoblastic leukemia (ALL) is a disease with an incidence of one to five cases per 100,000 population. Of these, $67 \%$ are B-ALL and $75 \%$ are produced in children under six years of age. The prognosis of the disease is defined by age, leukocyte count, genetic and molecular alterations, or initial response to treatment, among others [82]. Since this disease affects the pediatric population, it is even more important to avoid invasive tests, so liquid biopsies would represent an important advance.

In recent years, a management that takes into account the result of MRD has been imposed, such as in adults who may require allogeneic hematopoietic stem cell transplantation. For this, the most commonly used methods to date are multiparametric flow cytometry (more standardized) and PCR-based tests, such as in ALL with BCR/ABL1 mutation; NGS is not yet routinely used for MRD testing [83-85]. However, guidelines (e.g., NCCN) already recommend the use of NGS to detect IGH and TCR rearrangements as a marker for MRD. A comparison of MRD levels in ALL patients detected by IG/TR RTqPCR vs. $B C R-A B L 1$ genomic transcript quantification showed a good correlation, and the sensitivity significantly increases when large numbers of cells are acquired [86]. In adult patients with ALL undergoing cellular therapies ((hematopoietic cell transplantation and chimeric antigen receptor T cell therapies), the authors demonstrated a strong concordance between NGS-based MRD detected in the PB and BM $(r=0.87 ; p=0.001)$, with a sensitivity and specificity of MRD detection in the PB of $87 \%$ and $90 \%$, respectively, relative to MRD in the BM [87].

The use of liquid biopsies (cfDNA) in MRD in ALL has been explored in some studies. van der Velden et al. studied Ig/TCR rearrangements in T-ALL and its precursor in bone marrow and PB samples, finding a strong correlation in the MRD levels in T-ALL, but not in precursor B-ALL [88]. Schwarz et al. conducted one of the first studies to see that there was more plasma DNA in patients with ALL than in healthy patients [89]. Cheng et al. compared flow cytometry in bone marrow and peripheral blood plasma PCR quantifying $I g / T C R$ gene rearrangements; they did not show a correlation, but peripheral blood could predict relapse [90]. Another study showed that BCR/ABL1-positive ALL patients had lower pre-transplant cfDNA levels than $B C R / A B L 1$-negative ALL patients [91]. More studies are needed to use cfDNA for monitoring MRD in ALL.

Table 6. Liquid biopsies in lymphoblastic acute leukemia. 


\begin{tabular}{|c|c|c|c|c|c|}
\hline Target & Methods & $\begin{array}{c}\text { Cohort } \\
\text { size/disease stage }\end{array}$ & Evidence: Key points & Application & Ref. \\
\hline $\begin{array}{c}I g H / T C R \\
\text { rearrangements }\end{array}$ & RQ-PCR & $\begin{array}{c}\text { Precursor B-ALL, } n \\
\quad=62 \\
\text { T-ALL, } n=22 \\
\text { Diagnosis and } \\
\text { post-treatment }\end{array}$ & $\begin{array}{l}\text { - Strong correlation in MRD levels between } \\
\mathrm{BM} \text { and PB cfDNA }\left(r_{\mathrm{s}}=0.849 ; p<0.01\right) \text { in T-ALL, } \\
\text { not in precursor B-ALL }\end{array}$ & $\begin{array}{l}\text { Concordance } \\
\text { Response } \\
\text { assessment }\end{array}$ & {$[88]$} \\
\hline $\begin{array}{c}I g H / T C R \\
\text { rearrangements }\end{array}$ & $\begin{array}{l}\text { RQ-PCR in } \\
\text { plasma vs. } \\
\text { leucocytes }\end{array}$ & $\begin{array}{c}n=21(2-16 \text { years }) \\
\text { Diagnosis and } \\
\text { post-treatment }\end{array}$ & $\begin{array}{l}\text { - } \\
\text { High concordance }(86.7 \%) \text { between MRD } \\
\text { measurements in plasma and leukocytes } \\
\text { High DNA levels in ALL at diagnosis and } \\
\text { rapidly decrease after initiating treatment }\end{array}$ & Concordance & [89] \\
\hline $\begin{array}{c}I g H / T C R \\
\text { rearrangements }\end{array}$ & $\begin{array}{l}\text { RQ-PCR vs. } \\
\text { flow } \\
\text { cytometry }\end{array}$ & $\begin{array}{l}\quad n=206 \\
\text { Diagnosis and } \\
\text { post-treatment }\end{array}$ & 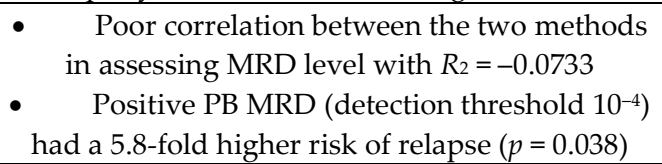 & $\begin{array}{c}\text { Response } \\
\text { assessment by } \\
\text { MRD } \\
\text { Prognostication }\end{array}$ & [90] \\
\hline
\end{tabular}

Ref., reference; ALL, acute lymphoblastic leukemia; RQ-PCR, real-time quantitative polymerase chain reaction; MRD, minimal residual disease; $\mathrm{PB}$, peripheral blood; cfDNA, cell-free DNA; $r_{\mathrm{s}}$, Spearman's rank correlation coefficient.

\subsection{Lymphomas and chronic lymphocytic leukemia (Table 7)}

Lymphomas are the most common hematologic malignancies, and the gold standard for their diagnosis is tissue or lymph node biopsy, with pathological examination after surgical resection or lymph node puncture; however, these are invasive examinations (sometimes, as in CNS (central nervous system) lymphoma, the sample may be not accessible) and a biopsy is not useful for monitoring the disease [92]. It is a heterogenous group of neoplasms, with significant differences in the treatment schemes, and non-Hodgkin lymphoma is the most frequent type [93].

Traditionally, imaging scans (including computed tomography (CT) and positron emission tomography (PET)) have been used to assess the response to treatment of lymphoma, which have several limitations such as lack of tumor specificity, inability to detect disease at the molecular level, inability to capture dynamic tumor processes, and radiation risk or cost, but the study of cfDNA may have advantages: A high tumor specificity, high sensitivity, broad applicability, and the ability to assess tumor heterogeneity [94]. The study of cfDNA in lymphomas includes cfDNA concentration, DNA methylation, detection of specific somatic mutations, and $\mathrm{IgH}$ gene rearrangement. Although the gold standard method for molecular profiling in lymphomas is based on lymph node or tissue biopsies, they have limitations. Lymphomas are not always expressed in peripheral blood, making it difficult to use the concept of "minimal residual disease" when employing conventional methods, and the use of "liquid biopsies" has obstacles in lymphomas: It is difficult to identify targets applicable to the diversity of these neoplasms. For example, IGH$B C L 2$ translocations may be detectable in the blood of patients with FL, transformed FL, and a subset of DLBCL, but there is a variability of the breakpoint regions [95].

\subsubsection{Diffuse large B cell lymphoma}

Diffuse large B cell lymphoma (DLBCL) is the most common type of newly diagnosed lymphoma cases. Three major molecular subtype categories of DLBCL have been defined: the activated $B$ cell-like (ABC) subtype, the germinal center $B$ cell-like (GCB) subtype, and the primary mediastinal BCL (PMBL) subtype.

Normal and tumor $B$ cells express the antigen receptor of B lymphocytes (BCR), composed of paired heavy and light immunoglobulin chains; there is a wide diversity in the characteristics of the molecule that results from the random rearrangement of the variable diversity joining (VDJ) in the progenitor B cells, producing unique clonotypes in each lymphoma, which may be useful in anticipating relapse in peripheral blood, if the relapse comes from the diagnosis clone. However, this technique has disadvantages: There are some DLBCLs with unproductive VDJ rearrangements. 
DLBCL is an aggressive and heterogeneous lymphoma, and studies have shown that cfDNA may have a position in the diagnosis of the disease. Various reports have shown a higher amount of cfDNA in patients with this lymphoma compared to healthy patients, a decrease in the amount of cfDNA when the treatment is effective, and a correlation between quantification of cfDNA and adverse prognosis of the disease [16,96-99].

Digital PCR (dPCR) has been used for detecting common mutations in DLBCL, such as XPO1 EF71K, EZH2 Y641, and MYD88 L265P. Roschewski et al. established the pertinence and prognostic impact of NGS-based molecular circulating tumor DNA monitoring in a retrospective cohort of 126 patients; detectable ctDNA in surveillance serum samples was a strong predictor for disease progression (with a HR of 228) [98,100-104].

Li et al. studied APP gene mutations using RT-PCR in 174 patients (98 DLBCL patients) and concluded that an increase in the cfDNA was associated with advanced stage disease, elevated LDH levels, and a higher prognosis score, with an inferior two-year PFS in patients with high levels of cfDNA [105].

In another study, presented by Rossi et al., a rapid clearance of mutations from cfDNA among the responsive patients with DLBCL treated with R-CHOP was demonstrated, using CAncer Personalized Profiling by deep Sequencing (CAPPseq) technology, as well as the persistence of basal mutations in the plasma cfDNA of refractory patients [106].

Kurtz et al. studied the dynamics of ctDNA from 217 patients with DLBCL using CAPPseq and assessed the prognostic value of ctDNA regarding risk factors; this study demonstrated that pretreatment ctDNA levels and molecular responses are independently prognostic of outcomes in DLBCL: A 2-log drop in ctDNA levels after two chemotherapy courses was associated with an eventual complete response and cure [107]. In another study, Rivas-Delgado et al. reported that high ctDNA levels were associated with a lower response [108,109].

Some studies have demonstrated that ctDNA can be an indicator of MRD before lymphoma relapse in DLBCL or T cell lymphoblastic lymphoma [102,110-112]. Shin et al. designed a panel of 66 genes associated with NHLs and analyzed the plasma cfDNA from patients with various subtypes using NGS; this study showed that the level of ctDNA was decreased in patients with response to therapy and increased in patients with disease progression [113]. However, we must be cautious because some reports have shown that some mutations, such as TP53 or DNMT3A, could have their origin in clonal hematopoiesis of indeterminate potential (CHIP) [99,114].

Monitoring MRD with ctDNA may be helpful following CAR-T cell therapy $[115,116]$.

\subsubsection{Mantle cell lymphoma}

Mantle cell lymphoma (MCL) is an aggressive lymphoma with a survival median of more than five years. Management is variable depending on risk and patient performance status, and includes chemotherapy, immunotherapy, or autologous stem cell transplantation. MRD is not very standardized, although some studies have been conducted using PCR amplification of $\mathrm{IgH}$ rearrangements, demonstrating an impact on the clinical outcome of the patient after autologous transplantation [117-119]. Lakhotia et al. used NGS to detect Ig heavy and light chains and CCND1 and BCL2 gene mutations in ctDNA; they concluded that baseline ctDNA correlated with total metabolic tumor volume on the PET scans, the clearance of ctDNA after one cycle of DA-EPOCH-R + BZ was strongly associated with a superior median PFS (76.4 vs. 20.7 months, $p=0.0037$ ) and a trend toward superior four-year overall survival (OS) $(92.3 \%$ vs. $73.0 \%, p=0.23)$, and that the clearance of ctDNA after two cycles of DA-EPOCH-R + BZ was also associated with a superior median progression-free survival (PFS) (32.4 vs. 21.4 months, $p=0.015)$ and a trend toward superior median OS (82.2 vs. 73.2 months, $p=0.15)$ [120]. Agarwal et al. reported that ctDNA provides valuable prognostic information and enables real-time assessment of tumor evolution [121]. 


\subsubsection{Follicular lymphoma}

Follicular lymphoma (FL) is the most common indolent lymphoma, and it usually has a prolonged survival (more than 10 years), but the prognosis is variable; treatment consists of immunotherapy (anti CD-20) with or without chemotherapy [122].

Sarkozy et al. reported a study with 133 patients using NGS to detect VDJ mutations, showing that a high ctDNA level is associated with a worse PFS (HR $=6.2,95 \%$ CI 2-162, $p=0.001)(p=0.14,0.52$, and 0.25 for FLIPI, bone marrow involvement, and the presence of circulating lymphoma cells, respectively) [123].

Delfau-Larue et al. tried to correlate CTCs, cfDNA, and total metabolic tumor volume (TMTV) with patients' outcomes using ddPCR and the $I g H$ rearrangements, and they reported that CTCs and cfDNA were correlated with TMTV, and that four-year PFS was lower in patients with TMTV $>510 \mathrm{~cm} 3(p=0.0004)$, CTCs $>0.0018$ PB cells $(p=0.03)$, or cfDNA >2550 equivalent-genome/mL ( $p=0.04)$ [124]. Another study using NGS in 29 patients with FL showed that MRD positivity in the interim or at the end of treatment results in significantly inferior PFS (median 12 months vs. not reached, $p=0.009$ ) [125].

\subsubsection{Primary central nervous system lymphoma}

Primary central nervous system lymphoma (PCNSL) is an aggressive and infrequent lymphoma [126]. In this lymphoma, the MYD88 L265P mutation has been studied in cfDNA using PCR and targeted deep sequencing (TDS): Hattori et al. found this mutation in diagnostics in the majority of patients, but, after chemotherapy, the mutation was undetectable; Yoon et al. concluded that using ctDNA has limited value for predicting treatment outcomes because it has a low detection efficiency [127,128]. Moreover, for diagnosis, it may be useful to detect the MYD88 L265P mutation in the cfDNA from cerebrospinal fluid [129-131].

\subsection{5. $\mathrm{T}$ cell lymphomas}

In $\mathrm{T}$ cell lymphomas, less common than B cell lymphomas, there is less evidence for the use of liquid biopsy. For diagnosis and to determine the mutational landscape, as in angioimmunoblastic T cell lymphoma, detection of HOAG17V/IDH2R172 mutations primarily takes place using allele-specific polymerase chain reaction (AS-PCR). However, in a previous study with 20 patients, it was not possible to demonstrate an association between mutations and clinical parameters or survival [132]. Milkjovic et al. used dPCR to detect TCR rearrangements in 34 patients with peripheral T cell lymphoma (PTCL), and reported that a median 2.6-log decrease in their ctDNA level after the first two cycles of treatment and that early clearance of ctDNA after cycle 2 was not associated with a statistically significant improvement in EFS (median (95\% CI), 8.4 (0.1-NR) vs. 2.0 (0.1-NR) years; $p=0.32)$ or OS (median, $8.4(0.3-\mathrm{NR})$ vs. $7.0(0.5-\mathrm{NR})$ years; $p=0.44)$ [133].

\subsubsection{Hodgkin lymphoma}

Hodgkin lymphoma (HL) represents $10 \%$ of newly diagnosed lymphomas; the standard initial treatment is chemotherapy and/or radiotherapy, with a five-year progressionfree survival rate of $65 \%-90 \%[134,92]$. Studies have been conducted in the attempt to detect peripheral blood mutations in cfDNA using NGS, finding that XPO1 E571K, ATM, KMT2D, and TP53 are frequently mutated in HL[135,136].

In 2018, Spina et al. clarified the genetic landscape of classic HL using CAPP-seq on cfDNA, establishing that STAT6, TNFAIP3, ITPKB, GNA13, B2M, ATM, SPEN, and XPO1 are the most commonly mutated genes [137].

Regarding MRD, Camus et al. reported that the XPO1 E571K mutation may be used as a biomarker in classical HL, using digital PCR, because in their study, patients with a detectable XPO1 mutation at the end of treatment could have a shorter free progression survival, but the results were not statistically significant [138]. 
Additionally, Spina et al. reported that a greater than 2-log reduction in cfDNA between diagnosis and after two chemotherapy courses was linked to a complete metabolic response and cure, but these studies have several limitations and more evidence is needed to incorporate liquid biopsies into the monitoring of MRD in lymphomas [133,137].

\subsubsection{Chronic lymphocytic leukemia}

Chronic lymphocytic leukemia (CLL) is the most common leukemia in the Western world, and it has a variable clinical outcome [139]. In CLL, MRD is not as well implemented as in other hematologic malignancies, but more and more studies reflect its importance in achieving better progression-free and overall survival [140-142]. The most widely used techniques are MFC and RQ-PCR. Although this is a circulating disease in peripheral blood, some studies have demonstrated the usefulness of ctDNA using digital PCR and targeted sequencing in obtaining a wide mutational landscape of the disease or when the disease is localized in an organ, as well as to assess clonal evolution. More studies are needed to implement MRD monitoring as a complementary method to those currently used [143].

Table 7. Liquid biopsies in lymphomas and chronic lymphocytic leukemia.

\begin{tabular}{|c|c|c|c|c|c|}
\hline Target & Methods & $\begin{array}{c}\text { Cohort } \\
\text { size/disease } \\
\text { stage }\end{array}$ & Evidence: Key points & Application & Ref. \\
\hline$\beta$-globin gene & qPCR & $\begin{array}{c}n=142 \\
\text { DLBCL, } n= \\
63 \\
\text { FL, } n=24 \\
\text { MCL, } n=10 \\
\text { HL, } n=45\end{array}$ & $\begin{array}{l}\text { - } \\
\text { vanced stage disease, B symptoms, elevated LDH levels, and age > } \\
60 \text { years } \\
\text { - } \quad \text { In HL, histological signs of necrosis and grade } 2 \text { nodular } \\
\text { sclerosis were associated with increased plasma DNA } \\
\text { - } \quad \text { Elevated plasma DNA levels were associated with an infe- } \\
\text { rior failure-free survival in patients with HL }(p=0.01) \text { and DLBCL } \\
(p=0.03)\end{array}$ & $\begin{array}{l}\text { Concordance } \\
\text { Prognosis }\end{array}$ & [16] \\
\hline $\begin{array}{l}\text { IgH gene } \\
\text { rearrangements }\end{array}$ & $\begin{array}{l}\text { Locus- } \\
\text { specific } \\
\text { primer sets } \\
\text { por IgH } \\
\text { and IgK }\end{array}$ & $\begin{array}{l}\quad n=17 \\
\text { DLBCL, } n= \\
15 \\
\text { MLBCL, } n=2 \\
\text { Diagnosis } \\
\text { and post- } \\
\text { treatment }\end{array}$ & $\begin{array}{l}\text { - No correlation between the level of ctDNA and clinical } \\
\text { characteristics } \\
\text { - No correlation between the level of ctDNA and the LDH } \\
\text { level }\end{array}$ & $\begin{array}{c}\text { Response } \\
\text { assessment } \\
\text { Prognosis }\end{array}$ & [100] \\
\hline $\begin{array}{l}I g H / T C R \\
\text { rearrangements }\end{array}$ & $\begin{array}{l}\text { RQ-PCR } \\
\text { NGS }\end{array}$ & $\begin{array}{c}n=68 \\
\text { B-NHL, } n= \\
37 \\
\text { T-NHL, } n= \\
10 \\
\text { HL, } n=5 \\
\text { CLL, } n=16 \\
\text { Pre- and } \\
\text { post-HSCT }\end{array}$ & $\begin{array}{l}\text { Detectable ctDNA three months after HSCT had inferior } \\
\text { PFS ( } p=0.033) \text { and an increased risk of relapse/progression }(p= \\
0.0006) \\
\text { - } 89 \% \text { of patients with relapse or progression had detectable } \\
\text { ctDNA prior or at the time of progression }\end{array}$ & $\begin{array}{l}\text { Prognosis } \\
\text { MRD }\end{array}$ & [103] \\
\hline Somatic gene & $\begin{array}{l}\text { Targeted } \\
\text { NGS }\end{array}$ & $\begin{array}{c}n=32 \\
\text { B-NHL, } n= \\
18 \\
\text { NK or T- } \\
\text { NHL, } n=9 \\
\text { Other, } n=5\end{array}$ & $\begin{array}{l}\text { - } \quad \text { tDNA at the time around CR/PR displayed a dramatic de- } \\
\text { crease in the VAF and number of variants } \\
\text { PD displayed a significant elevation of the ctDNA level in } \\
\text { VAF }\end{array}$ & Concordance & [113] \\
\hline$A P P$ gene & RT-PCR & $n=174$ & $\begin{array}{l}\text { - Lymphoma patients had a higher mean level of cfDNA } \\
\text { compared to healthy donors }(p>0.0001)\end{array}$ & Prognosis & [105] \\
\hline
\end{tabular}




\begin{tabular}{|c|c|c|c|c|c|}
\hline & & $\begin{array}{c}\text { DLBCL, } n= \\
98 \\
\text { HL, } n=18 \\
\text { TCL, } n=9 \\
\text { NK/T cell } \\
\text { lymphoma, } n \\
=21 \\
\text { Other B- } \\
\text { NHL, } n=28 \\
\text { Diagnosis }\end{array}$ & $\begin{array}{c}\text { Increase in cfDNA was associated with an advanced stage } \\
\text { disease, elevated LDH levels, and a higher prognosis score } \\
\text { - In patients with DLBCL, high levels of cfDNA showed an } \\
\text { inferior two-year PFS }\end{array}$ & & \\
\hline $\begin{array}{l}\text { IgH gene } \\
\text { rearrangements }\end{array}$ & $\begin{array}{l}\text { NGS } \\
\text { (ctDNA) } \\
\text { and PCR } \\
\text { vs. CT }\end{array}$ & $\begin{array}{l}\text { DLBCL, } n= \\
\quad 126 \\
\text { Diagnosis } \\
\text { and post- } \\
\text { treatment }\end{array}$ & $\begin{array}{l}\text { - } \quad \text { ctDNA may be a sensitive and specific measure of disease } \\
\text { Detectable ctDNA means a HR of } 228 \text { for clinical progres- } \\
\text { sion } \\
\text { Patients with early-stage (1 or } 2 \text { ) disease have a lower } \\
\text { ctDNA, and their LDH level correlates with ctDNA level }\end{array}$ & $\begin{array}{c}\text { Response } \\
\text { assessment } \\
\text { Staging }\end{array}$ & [102] \\
\hline $\begin{array}{l}\text { IgH gene } \\
\text { rearrangements }\end{array}$ & $\begin{array}{l}\text { Ig-HTS vs. } \\
\text { PET/CT }\end{array}$ & $\begin{array}{l}\text { DLBCL, } n= \\
75 \\
\text { Diagnosis or } \\
\text { recurrence }\end{array}$ & $\begin{array}{l}\text { - cfDNA correlates with tumor burden measured by PET/CT } \\
\qquad(p=0.002) \\
\text { - } \quad \text { kfDNA correlates with PET/CT better than circulating leu- } \\
\text { kocytes } \\
\text { cfDNA was better detected in relapse }(p=0.001) \text { and pre- } \\
\text { cedes PET/CT detection of relapse }(p<0.0001)\end{array}$ & $\begin{array}{l}\text { Surveillance } \\
\text { after complete } \\
\text { remission }\end{array}$ & [101] \\
\hline $\begin{array}{l}\text { Somatic } \\
\text { mutations }\end{array}$ & $\begin{array}{l}\text { CAPP-seq } \\
\text { Ultra-deep } \\
\text { targeted } \\
\text { NGS }\end{array}$ & $\begin{array}{l}\text { DLBCL, } n= \\
\quad 30 \\
\text { Diagnosis } \\
\text { and post- } \\
\text { treatment }\end{array}$ & $\begin{array}{l}\text { - Rapid clearance of DLBCL mutations in the cfDNA of re- } \\
\text { sponding patients }\end{array}$ & $\begin{array}{l}\text { Response } \\
\text { assessment }\end{array}$ & [106] \\
\hline $\begin{array}{l}V(D) J \\
\text { rearrangements }\end{array}$ & NGS & $\begin{array}{l}\text { DLBCL, } n=6 \\
\text { Pre and post- } \\
\text { CAR-T cell } \\
\text { therapy }\end{array}$ & $\begin{array}{l}\text { - MRD by ctDNA correlated with clinical and radiological } \\
\text { outcomes for all patients at day }+28 \\
\text { - Increasing ctDNA temporally preceded PD in a majority of } \\
\text { patients }(4 / 5) \text { and all patients }(5 / 5) \text { had increasing ctDNA at the } \\
\text { time of PET-CT-confirmed PD } \\
\text { - The calculated MTV pre-CAR and on day } 28 \text { showed a } \\
\text { strong correlation }\end{array}$ & $\begin{array}{l}\text { MRD } \\
\text { Concordance }\end{array}$ & [115] \\
\hline$L 1 P A 2$ & qPCR & $\begin{array}{l}\text { DLBCL, } n= \\
40 \text { (and } 38 \\
\text { controls) } \\
\text { Diagnosis }\end{array}$ & $\begin{array}{l}\text { - Higher cfDNA in DLBCL patients than in control patients } \\
\text { cfDNA level showed an association with }>60 \text { years, B } \\
\text { symptoms, IPI score, and different disease staging } \\
\text { The elevated concentrations of plasma cfDNA correlated } \\
\text { with OS }(p=0.022)\end{array}$ & Prognosis & [97] \\
\hline Somatic gene & CAPP-seq & $\begin{array}{l}\text { DLBCL, } n= \\
\quad 217 \\
\text { Diagnosis, } \\
\text { relapse, or } \\
\text { recurrence }\end{array}$ & $\begin{array}{l}\text { Pretreatment levels were prognostic in front-line and sal- } \\
\text { vage settings } \\
\text { Patients receiving front-line therapy achieving EMR (with a } \\
\text { 2-log decrease after one cycle) or MMR (a 2.5-log decrease after } \\
\text { two cycles) had superior outcomes at } 24 \text { months }\end{array}$ & Prognosis & [107] \\
\hline Somatic gene & $\begin{array}{l}\text { Targeted } \\
\text { NGS }\end{array}$ & $\begin{array}{l}\text { DLBCL, } n= \\
\quad 79 \\
\text { Diagnosis } \\
\text { and post- } \\
\text { treatment }\end{array}$ & $\begin{array}{l}\text { - A higher amount of ctDNA significantly correlated with tu- } \\
\text { mor burden (clinical parameters and MTV) } \\
\text { High ctDNA levels }(>2.5 \text { log hGE/mL) were associated with } \\
\text { lower CR }(65 \% \text { vs. } 96 \%, p<0.004), \text { shorter PFS }(65 \% \text { vs. } 85 \%, p= \\
0.038) \text {, and OS at two years }(73 \% \text { vs. } 100 \%, p=0.007)\end{array}$ & $\begin{array}{l}\text { Concordance } \\
\text { Prognosis }\end{array}$ & [108] \\
\hline $\begin{array}{l}\text { Ig heavy and } \\
\text { light chains and } \\
C C N D 1 \text { and } \\
B C L 2 \text { genes }\end{array}$ & NGS & $\begin{array}{c}\text { MCL, } n=53 \\
\text { Diagnosis } \\
\text { and post- } \\
\text { treatment }\end{array}$ & $\begin{array}{l}\text { - Baseline ctDNA correlated with total metabolic tumor vol- } \\
\text { ume on PET scan }\left(r_{s}=0.74\right) \text { but was not associated with PFS ( } p= \\
0.45) \text { or OS ( } p=0.22) \\
\text { - Clearance of ctDNA after one cycle of DA-EPOCH-R + BZ } \\
\text { was strongly associated with a superior median PFS (76.4 vs. } 20.7 \\
\text { months, } p=0.0037) \text { and a trend toward superior four-year OS } \\
(92.3 \% \text { vs. } 73.0 \%, p=0.23)\end{array}$ & $\begin{array}{l}\text { Concordance } \\
\text { Prognosis }\end{array}$ & [120] \\
\hline
\end{tabular}




\begin{tabular}{|c|c|c|c|c|c|}
\hline & & & $\begin{array}{c}\text { Clearance of ctDNA after two cycles of DA-EPOCH-R + BZ } \\
\text { was also associated with a superior median PFS (32.4 vs. } 21.4 \\
\text { months, } p=0.015) \text { and a trend toward superior median OS }(82.2 \\
\text { vs. } 73.2 \text { months, } p=0.15)\end{array}$ & & \\
\hline$V(D) J$ gene & NGS & $\begin{array}{l}\text { FL, } n=133 \\
\text { Diagnosis } \\
\text { and post- } \\
\text { treatment }\end{array}$ & $\begin{array}{l}\text { - High ctDNA level was associated with a worse PFS (HR = } \\
6.2,95 \% \text { CI } 2-162, p=0.001)(p=0.14,0.52 \text {, and } 0.25 \text { for FLIPI, bone } \\
\text { marrow involvement, and presence of circulating lymphoma cells, } \\
\text { respectively) } \\
\text { - Four patients with a high ctDNA level had a median PFS of } \\
\text { only } 9.8 \text { months versus not reached for the } 12 \text { patients with a low } \\
\text { ctDNA level }(p=0.002)\end{array}$ & $\begin{array}{l}\text { Concordance } \\
\text { Prognosis }\end{array}$ & [123] \\
\hline $\begin{array}{l}I g H \text { gene } \\
\text { rearrangements }\end{array}$ & ddPCR & $\begin{array}{l}\text { FL, } n=133 \\
\text { Diagnosis } \\
\text { and post- } \\
\text { treatment }\end{array}$ & $\begin{array}{l}\text { - Significant correlation between TMTV and both CTCs }(p< \\
0.0001) \text { and cfDNA }(p<0.0001) \\
\text { Four-year PFS was lower in patients with TMTV }>510 \mathrm{~cm}^{3} \\
(p=0.0004), \text { CTCs }>0.0018 \text { PB cells }(p=0.03) \text {, or cfDNA }>2550 \\
\text { equivalent-genome } / \mathrm{mL}(p=0.04)\end{array}$ & $\begin{array}{l}\text { Concordance } \\
\text { Prognosis }\end{array}$ & [124] \\
\hline $\begin{array}{l}\text { Somatic } \\
\text { mutations }\end{array}$ & NGS & $\begin{array}{l}\text { FL, } n=27 \\
\text { Diagnosis } \\
\text { and post- } \\
\text { treatment }\end{array}$ & $\begin{array}{l}\text { MRD positivity in the interim or at the end of treatment re- } \\
\text { sulted in significantly inferior PFS (median } 12 \text { months vs. not } \\
\text { reached, } p=0.009 \text { ) }\end{array}$ & $\begin{array}{l}\text { Concordance } \\
\text { Follow-up }\end{array}$ & [125] \\
\hline MYD88 gene & $\begin{array}{l}\text { ddPCR } \\
\text { TGS }\end{array}$ & $\begin{array}{l}\text { PCNSL, } n= \\
\quad 14 \\
\text { Diagnosis } \\
\text { and post- } \\
\text { treatment }\end{array}$ & $\begin{array}{l}\text { - MYD88 L265P mutation was found in tumor-derived DNA } \\
\text { from all } 14 \text { patients }(14 / 14,100 \%) \\
\text { - } \quad \text { Among } 14 \text { cell-free DNAs evaluated by ddPCR (14/14) and } \\
\text { TDS (13/14), the MYD88 L265P mutation was detected in eight out } \\
\text { of } 14 \text { (ddPCR) and in } 0 \text { out of } 13 \text { (TDS) samples, respectively } \\
\text { - After chemotherapy, the MYD88 L265P mutation in cell-free } \\
\text { DNA was traced in five patients; the mutations disappeared after } \\
\text { chemotherapy, and they remained undetectable in all patients }\end{array}$ & $\begin{array}{l}\text { Concordance } \\
\text { Follow-up }\end{array}$ & [127] \\
\hline MYD88 gene & ddPCR & $\begin{array}{l}\text { PCNSL, } n= \\
29 \\
\text { Diagnosis }\end{array}$ & $\begin{array}{l}\text { - MYD288 p.(L265P) was detected in 73\% CSF cfDNA sam- } \\
\text { ples and } 40 \% \text { of plasma samples }\end{array}$ & Concordance & [129] \\
\hline MYD88 gene & ddPCR & $\begin{array}{l}\text { PCNSL, } n= \\
11 \\
\text { Diagnosis } \\
\text { and relapse }\end{array}$ & MYD288 p.(L265P) was detected in $86 \%$ of the CSF samples & Concordance & [130] \\
\hline MYD88 gene & ddPCR & $\begin{array}{l}\text { PCNSL, } n= \\
42 \\
\text { Diagnosis }\end{array}$ & $\begin{array}{l}\text { - MYD88 mutation status was successfully determined in } 28 \\
\text { CSF cfDNA samples }(66.7 \%)\end{array}$ & Concordance & [131] \\
\hline $\begin{array}{l}\text { RHOAG17V and } \\
\text { IDH } 2 \text { R } 172 \\
\text { mutations }\end{array}$ & AS-PCR & $\begin{array}{l}\text { PCNSL, } n= \\
20 \\
\text { Diagnosis }\end{array}$ & $\begin{array}{l}\text { - } 14(70 \%) \text { and } 3(15 \%) \text { of the } 20 \text { patients generated AS-PCR } \\
\text { products indicative of the presence of RHOAG17V and IDH2R172 } \\
\text { - There was no association between } R H O A G 17 V / I D H 2 R 172 \\
\text { mutations and clinical parameters or survival }\end{array}$ & $\begin{array}{l}\text { Concordance } \\
\text { Response } \\
\text { assessment }\end{array}$ & [132] \\
\hline $\begin{array}{l}\text { TCR } \\
\text { rearrangements }\end{array}$ & $\mathrm{dPCR}$ & $\begin{array}{l}\text { PTCLs, } n= \\
\quad 34: \\
\text { ALCL, } n=10 \\
\text { PTCL-NOS, } \\
\quad n=10 \\
\text { Other, } n=14 \\
\text { Diagnosis }\end{array}$ & $\begin{array}{l}\text { Median 2.6-log decrease in the ctDNA level after the first } \\
\text { two cycles of treatment } \\
\text { Early clearance of ctDNA after cycle } 2 \text { was not associated } \\
\text { with a statistically significant improvement in EFS (median }(95 \% \\
\text { CI), } 8.4(0.1-N R) \text { vs. } 2.0(0.1-N R) \text { years; } p=0.32) \text { or OS (median, } 8.4 \\
(0.3-N R) \text { vs. } 7.0(0.5-N R) \text { years; } p=0.44) \\
\text { - In six (75\%) of the progressors, ctDNA was positive before } \\
\text { the detection of clinical relapse }\end{array}$ & $\begin{array}{l}\text { Response } \\
\text { assessment }\end{array}$ & [133] \\
\hline XPO1 gene & $\mathrm{dPCR}$ & $\begin{array}{l}\text { cHL, } n=94 \\
\text { Diagnosis } \\
\text { and post- } \\
\text { treatment }\end{array}$ & $\begin{array}{c}\text { - Concordance of the XPO1 E571K mutation dPCR results } \\
\text { within the } 50 \text { biopsy/plasma DNA pairs was highly significant }(p= \\
0.0179) \\
\text { - Patients with a detectable XPO1 mutation at the end of } \\
\text { treatment displayed a trend toward shorter two-year PFS, com- } \\
\text { pared to patients with undetectable mutations in plasma cell-free }\end{array}$ & $\begin{array}{l}\text { Concordance } \\
\text { Response } \\
\text { assessment } \\
\text { Prognosis } \\
\text { MRD }\end{array}$ & [138] \\
\hline
\end{tabular}


DNA (2-year PFS $=57.1 \%$, 95\% CI 30.1\%-100\% versus two-year PFS $=90.5 \%, 95 \%$ CI $78.8 \%-100 \%$, respectively, $p=0.0601$ )

\begin{tabular}{|c|c|c|c|c|}
\hline $\begin{array}{c}\text { NGS } \\
\text { CAPP-seq }\end{array}$ & $\begin{array}{l}\text { cHl, } n=112 \\
\quad \text { Newly } \\
\text { diagnosed, } n \\
\quad=80 \\
\text { Refractory, } n \\
\quad=32\end{array}$ & $\begin{array}{l}\text { A 2-log drop in ctDNA after two chemotherapy courses } \\
\text { was associated with a complete response and cure } \\
\text { A drop of less than 2-log in ctDNA after two ABVD courses } \\
\text { was associated with progression and inferior survival } \\
\text { ctDNA quantification after two chemotherapy courses may } \\
\text { have prognostic implications, and ctDNA may complement in- } \\
\text { terim PET/CT in informing on patients' outcomes }\end{array}$ & $\begin{array}{l}\text { Response } \\
\text { assessment } \\
\text { Prognosis }\end{array}$ & [137] \\
\hline $\begin{array}{l}\text { NFKBIE, } \\
\text { TNFAIP3, } \\
\text { STAT6, PTPN1, } \\
\text { B2M, XPO1, } \\
\text { ITPKB, GNA13, } \\
\text { and SOCS1 } \\
\text { genes }\end{array}$ & $\begin{array}{l}\text { HL, } n=60 \\
\text { Diagnosis } \\
\text { and post- } \\
\text { treatment }\end{array}$ & $\begin{array}{l}\text { - ctDNA concentration and genotype were correlated with } \\
\text { clinical characteristics and presentation } \\
\text { - No statistically significant difference between the concen- } \\
\text { tration of cfDNA (ng/mL of plasma) after C2 among DS 1-3 pa- } \\
\text { tients (35 patients, median } 35 \mathrm{ng} / \mathrm{mL} \text { (range: } 20.4-260 \text { ) versus DS } \\
4-5 \text { patients (seven patients, median } 36.2 \mathrm{ng} / \mathrm{mL} \text { (range: } 21.8-80), p \\
=0.79 \text { ) }\end{array}$ & & [136] \\
\hline \multicolumn{5}{|c|}{$\begin{array}{l}\text { Ref., reference; RQ-PCR, real-time quantitative polymerase chain reaction; MRD, minimal residual disease; PB, peripheral blood; cfDNA, cell- } \\
\text { Inon-Hodgkin lymphoma; HL, Hodgkin lymphoma; DLBCL, diffuse large B cell lymphoma; PTCL-NOS: peripheral T-cell lymphoma-no otherwise } \\
\text { specified; qPCR, quantitative PCR; FL, follicular lymphoma; MCL, mantle cell lymphoma; LDH, lactate dehydrogenase; ctDNA, circulant tumor } \\
\text { DNA; MLBCL, mediastinal large B cell lymphoma; HSCT, hematopoietic stem cell transplantation; PFS, progression-free survival; NGS, next-gener- } \\
\text { ation sequencing; VAF, variant allele frequency; PD, progressive disease; CT, computerized tomography; PET, positron-emission tomography; CAPP- } \\
\text { seq, CAncer Personalized Profiling by deep Sequencing; CAR, chimeric antigen receptor; OS, overall survival; MTV, metabolic tumor volume; EMR, } \\
\text { early molecular response; MMR, major molecular response; HR, hazard ratio; ddPCR, droplet digital PCR; FLIPI, Follicular Lymphoma International } \\
\text { Prognostic Index; TMTV, total MTV; PCNSL, primary central nervous system lymphoma; TDS, target deep sequencing; CSF, cerebrospinal fluid; AS- } \\
\text { PCR, allele-specific PCR; dPCR, digital PCR; DS, Deauville score. }\end{array}$} \\
\hline
\end{tabular}

\subsection{Multiple myeloma (Table 8)}

Multiple myeloma (MM) is a clonal plasma cell proliferative disorder characterized by bone lesions, whose diagnosis is based on the presence of clinical, biochemical, histopathological, and radiological markers of disease. The appearance of new drugs and the improvement of supportive treatment has produced an increase in the median survival, which is currently estimated at five years in developed countries [144,145].

MRD in MM has been shown to be a predictive factor for PFS and OS; it is performed by multiparametric flow cytometry (MFC) or by allele-specific oligonucleotide PCR (ASOPCR) sequencing in bone marrow, with a sensitivity of $10^{-5}-10^{-6}[146-149]$ or by NGS to detect $I g H$ rearrangements with a sensitivity of $10^{-6}[150]$.

$\mathrm{MM}$ is a disease of complex molecular biology, with different clones of malignant plasma cells in the same patient; these clones evolve in the natural history of the disease. Several genes are involved in many patients, such as KRAS, NRAS, or BRAF [151,152]. In $\mathrm{MM}$, circulating tumor cells are released from the primary tumor into the bloodstream, usually reaching another location in the bone marrow; this process is early in carcinogenesis. Different groups have studied circulating tumor cells in MM and other plasma cell dyscrasias; they can be particularly useful in extramedullary, oligosecretory, and non-secretory disease settings [153-158].

As in other hematologic neoplasms, circulating tumor DNA can be analyzed in MM through tumor-specific mutations or genetic aberrations. In recent years, the number of articles on this subject has increased. In 2015, Sata et al. evaluated the tumor burden in mRNA from peripheral blood cells, whole bone marrow cells, the CD20+CD38L B cell population in bone marrow, and cell-free DNA from the sera of patients with MM, and compared them using ASO-PCR. This study, with 30 patients, found statistically significant correlations between the ASO-PCR levels in bone marrow cells and peripheral blood cells, which suggests that clonogenic plasma cells or MM precursor cells may circulate in peripheral blood, but the ASO-PCR values in the cell-free DNA from sera did not correlate with those in either bone marrow or peripheral blood cells [159].

Oberle et al. conducted a study in $27 \mathrm{MM}$ patients to explore the clonotypic V(D)J rearrangement for monitoring circulating myeloma cells and cell-free myeloma DNA; 
positivity for circulating myeloma cells/cell-free myeloma was associated with conventional remission status, and the majority of non-responders/progressors had evidence of persistent circulating myeloma cells/cell-free myeloma DNA. However, positivity for circulating myeloma cells and for cell-free myeloma DNA were discordant in $30 \%$ of cases, which indicates that cell-free myeloma DNA may not be generated entirely by circulating myeloma cells and may reflect the overall tumor burden [160].

Mithraprabhu et al. analyzed plasma-derived circulating free tumor DNA as an adjunct to bone marrow biopsies for mutational characterization (for KRAS, NRAS, BRAF, and TP53) and for tracking disease progression in 33 relapsed/refractory and 15 newly diagnosed MM patients, in comparison to 12 healthy donors by NGS, showing a higher amount of cfDNA in MM patients. Some mutations were found only in cfDNA. Although there were few patients in the study, it may confirm the spatial heterogeneity of MM [161].

Rustad et al. explored the presence of circulating tumor DNA monitoring recurrent mutations (NRAS, KRAS, and BRAF) using ddPCR, comparing it to bone marrow plasma cells, and they observed a correlation between the concentration of mutated alleles in serum and the fraction in bone marrow plasma cells, which may reflect mutated cells, total tumor mass, and transformation to a more aggressive disease, being complementary to $\mathrm{M}$ protein [162].

Gerber et al. studied cfDNA in 28 patients, identifying the clonotypic $V(D) J$ rearrangement as a marker, or genotyping a limited set of genes and designed a panel of NGS, comparing the characteristics of these patients to samples of bone marrow aspirates from patients with plasma cell disorders in different stages; the amount of cfDNA correlated with some parameters that may indicate tumor burden, such as the percentage of plasma cell infiltration of bone marrow [163].

Biancon et al. analyzed the disease evolution of $25 \mathrm{MM}$ patients receiving second-line therapy, and the study showed that levels of $I g H$ detected in cfDNA reflected the number of PCs enumerated by MFC and correlated with clinical outcomes [164].

Other studies have shown that cell-free tumor DNA can be used to obtain the molecular profile of myeloma instead of bone marrow aspirate, and have supported the concept of cell-free DNA as a prognostic marker [165-167]. In a recent study, after sorting $77 \mathrm{MM}$ patients according to their molecular risk, Deshpande et al. found that cfDNA was higher in high-risk MM, and high cfDNA levels were associated with a worse PFS and OS [168]. In other study, Manzoni et al. analyzed 104 samples from 65 patients (15 monoclonal gammopathy of undetermined significance-MGUS; 33 smoldering multiple myeloma-SMM; and $17 \mathrm{MM}$ ) using ultra-deep NGS, concluding that a lower tumor mass correlates with a lower cfDNA tumor fraction, and it could be useful to evaluate MGUS and SMM in the future [169].

Regarding the study of MRD with cfDNA, there are few published studies that compare it to currently standardized methods (flow cytometry and DNA sequencing in bone marrow) [170]. Mazzotti et al. demonstrated the absence of a correlation between ctDNA and bone marrow for MRD by NGS, using only IgH gene rearrangements, although only 37 patients were included [171]. Long et al. analyzed 22 plasma samples from eight extramedullary multiple myeloma (EMM) and 23 plasma samples from $10 \mathrm{MM}$ patients without extramedullary spread, with higher cfDNA concentrations in patients with extramedullary spread. After designing sequencing panels targeting the coding sequence regions of the same 22 recurrently mutated genes, 17 different were detected; the authors concluded that cfDNA can be used to track extramedullary disease progression, including MRD, when plasmacytomas are inaccessible [172].

In other studies, a significant correlation of quantity of tumor-specific cell-free DNA levels with clinically meaningful events has been found, but the results in the case of MRD monitoring were not significant [166,173]; target sequencing of cfDNA cannot today achieve the sensitivity of MRD detection of flow cytometry or PCR; however, in the future, MRD detection in cell-free DNA may increase its sensitivity combining parameters (patient-specific mutation panels, methylation patterns, copy number alterations, or $\mathrm{IgH}$ rearrangements) and may add further accuracy to progression-free survival prediction and 
detection of false-negative MRD [174-176]. At the present time, the isolated use of cfDNA has no clinical applicability in the study of MRD in multiple myeloma, although there is increasing evidence, which may initially make it a complementary test for the follow-up of the disease and, in the future, with its improvement, into a fundamental tool for the evaluation of MRD [158].

Table 8. Liquid biopsies in lymphomas and chronic lymphocytic leukemia.

\begin{tabular}{|c|c|c|c|c|c|}
\hline Target & Methods & $\begin{array}{c}\text { Cohort size/disease } \\
\text { stage }\end{array}$ & Evidence: Key points & Application & Ref. \\
\hline IgH gene & ASO-PCR & $\begin{array}{l}\quad n=30 \\
\text { Diagnosis and post- } \\
\text { treatment }\end{array}$ & $\begin{array}{l}\text { - } \quad \text { Myeloma cell-derived } I g H \text { DNA fragments } \\
\text { in the sera stayed at similar levels and sometimes } \\
\text { increased during treatment }\end{array}$ & Concordance & [159] \\
\hline $\begin{array}{l}V(D) J \\
\text { rearrangement }\end{array}$ & NGS & $\begin{array}{l}\quad n=27 \\
\text { Diagnosis and post- } \\
\text { treatment }\end{array}$ & $\begin{array}{l}\text { - At the follow-up, cfm- } V(D) J \text { in } 34 \% \text { of sam- } \\
\text { ples } \\
\text { - } \quad \text { Clear associations were observed between } \\
\text { poor remission status and evidence of cfm-V(D)J } \\
\text { (regression coefficient } 1.49 ; p=0.001 \text { ) }\end{array}$ & $\begin{array}{l}\text { Concordance } \\
\text { Prognosis }\end{array}$ & [160] \\
\hline $\begin{array}{l}\text { KRAS, NRAS, } \\
B R A F, \text { and TP53 } \\
\text { mutations }\end{array}$ & $d d P C R$ & $\begin{array}{c}n=60 \\
\text { New diagnosis, } n= \\
15 \\
\text { Relapse/refractory, } n \\
=33 \\
\text { Diagnosis and post- } \\
\text { treatment } \\
\text { Normal volunteers, } \\
n=12\end{array}$ & $\begin{array}{l}\text { - ctDNA analysis in seven patients revealed } \\
\text { an increase in the AF of specific mutant clones co- } \\
\text { incident with clinical relapse or a potential nonin- } \\
\text { vasive monitoring of MM disease progression }\end{array}$ & $\begin{array}{l}\text { Concordance } \\
\text { Response } \\
\text { assessment }\end{array}$ & [161] \\
\hline $\begin{array}{l}\text { NRAS, KRAS, } \\
\text { and BRAF } \\
\text { mutations }\end{array}$ & ddPCR & $\begin{array}{c}\text { n }=18 \\
\text { Diagnosis and post- } \\
\text { treatment }\end{array}$ & $\begin{array}{l}\text { - } 12 / 14 \text { mutated clones were detectable in the } \\
\text { serum at each relapse and covaried with M pro- } \\
\text { tein }\end{array}$ & $\begin{array}{l}\text { Concordance } \\
\text { Response } \\
\text { assessment }\end{array}$ & [162] \\
\hline $\begin{array}{l}\text { KRAS, NRAS, } \\
B R A F, E G F R, \\
\text { and PIK3CA } \\
\text { mutations }\end{array}$ & ddPCR & $\begin{array}{l}\quad n=53 \\
\text { New diagnosis, } n= \\
\quad 11 \\
\text { Relapsed, } n=42\end{array}$ & $\begin{array}{l}\text { - Higher cfDNA concentrations in MM co- } \\
\text { hort compared to } 56 \text { patients with advanced solid } \\
\text { tumors }(p<0.001) \\
\text { - Concentrations of cfDNA correlated with } \\
\text { advanced disease (late relapse compared to early } \\
\text { relapse; } p=0.016) \\
\text { - Mutant AFs were highly concordant be- } \\
\text { tween cfDNA and BM }\left(R^{2} \text { range, } 0.913-0.997\right)\end{array}$ & $\begin{array}{l}\text { Concordance } \\
\text { Prognosis }\end{array}$ & [165] \\
\hline $\begin{array}{l}\text { Somatic } \\
\text { mutations }\end{array}$ & CAPP-seq & $\begin{array}{c}n=28 \\
\text { New diagnosis, } n= \\
25 \\
\text { Relapsed/refractory, } \\
n=3 \\
\text { Diagnosis }\end{array}$ & $\begin{array}{l}\text { The amount of cfDNA correlated with clini- } \\
\text { cal-pathological parameters reflecting tumor } \\
\text { load/extension, including BM PC infiltration }\left(r_{s}=\right. \\
0.42, p=0.02) \\
\text { - Variant allele frequencies in the plasma } \\
\text { samples correlated with those in tumor biopsies } \\
\left(r_{s}=0.58, p=9.6 \times 10^{-5}\right)\end{array}$ & Concordance & [163] \\
\hline $\begin{array}{l}\text { IgH gene } \\
\text { rearrangements }\end{array}$ & ddPCR & $\begin{array}{l}\quad n=25 \\
\text { At first relapse }\end{array}$ & $\begin{array}{l}\text { - Patients with levels } 4.7 \%(n=12) \text { of the tu- } \\
\text { mor-associated IgH sequence before therapy had } \\
\text { significantly inferior PFS (median values, } 268 \text { vs. } \\
990 \text { days; HR }=3.507, p=0.04988, \text { logrank test) } \\
\text { - High level of correlation between cfDNA } \\
\text { NGS and MFC data ( } r=0.5831, p=0.0044 \text {, Pear- } \\
\text { son's correlation test) }\end{array}$ & $\begin{array}{l}\text { Concordance } \\
\text { Prognosis }\end{array}$ & [164] \\
\hline $\begin{array}{l}\text { IgH gene } \\
\text { rearrangements }\end{array}$ & NGS & $\begin{array}{l}\quad n=37 \\
\text { Post-treatment }\end{array}$ & $\begin{array}{l}-\quad \text { Minimal correlation between myeloma } \\
\text { ctDNA detection at the time of MRD in the BM } \\
\text { and quantity of analyzed cell-free DNA ( } r=0.46 ; p \\
=0.001)\end{array}$ & MRD & [171] \\
\hline
\end{tabular}




\begin{tabular}{|c|c|c|c|c|c|}
\hline $\begin{array}{c}\text { Somatic } \\
\text { mutations }\end{array}$ & WES & $\begin{array}{c}n=163 \\
\text { cfDNA, } n=107 \\
\text { CTCs, } n=56 \\
\text { Diagnosis }\end{array}$ & $\begin{array}{l}\text { - Concordance in clonal somatic mutations } \\
(\sim 99 \%) \text { and copy number alterations }(\sim 81 \%) \text { be- } \\
\text { tween liquid and tumor biopsies }\end{array}$ & Concordance & [173] \\
\hline $\begin{array}{c}\text { Somatic } \\
\text { mutations }\end{array}$ & WES & $\begin{array}{l}\quad n=105 \\
\text { MM patients, } n=93 \\
\text { Healthy patients, } n= \\
12 \\
\text { Diagnosis }\end{array}$ & $\begin{array}{l}\text { - } \quad 90.5 \% \text { of all CNV segments in the BM were } \\
\text { concordant with cfDNA, whereas } 9.5 \% \text { were dis- } \\
\text { cordant }\end{array}$ & Concordance & [174] \\
\hline $\begin{array}{l}\text { Somatic } \\
\text { mutations }\end{array}$ & $\begin{array}{l}\text { Ultra-deep } \\
\text { NGS }\end{array}$ & $\begin{array}{c}n=65 \\
\text { MGUS, } n=15 \\
\text { SMM, } n=33 \\
\text { MM, } n=17 \\
\text { Diagnosis }\end{array}$ & $\begin{array}{l}\text { - cfDNA concentrations were significantly } \\
\text { lower in MGUS and SMM (on average, 2.8-fold) } \\
\text { lower than in MM ( } p=0.02)\end{array}$ & $\begin{array}{c}\text { Concordance } \\
\text { Prognosis }\end{array}$ & [169] \\
\hline $\begin{array}{l}\text { Somatic } \\
\text { mutations }\end{array}$ & NGS & $\begin{array}{c}n=18 \\
\text { EMM patients, } n=8 \\
\text { MM without EM } \\
\text { spread, } n=10 \\
\text { Diagnosis }\end{array}$ & $\begin{array}{l}\text { - } \quad \text { ctDNA exhibited strong concordance with } \\
\text { time-matched extramedullary plasmacytoma bi- } \\
\text { opsies }\left(p=8.66 \times 10^{-7}\right)\end{array}$ & Concordance & [172] \\
\hline $\begin{array}{l}\text { Somatic } \\
\text { mutations }\end{array}$ & Targeted NGS & $\begin{array}{l}n=77 \\
\text { Newly diagnosed, } n \\
\quad=52 \\
\text { Relapsed, } n=2 \\
\text { Previously treated, } n \\
\quad=23\end{array}$ & $\begin{array}{l}\text { Weak correlation between ISS and cfDNA } \\
\text { levels }(r=0.32, p=0.005) \\
\text { - A weak correlation was seen with the } \\
\text { cfDNA concentration and LDH levels }(r=0.44, p< \\
0.0001) \\
\text { cfDNA levels correlated weakly with serum } \\
\beta 2 \mathrm{~m}(r=0.33, p=0.003) \\
\text { Correlation between GEP70 risk score with } \\
\text { cfDNA levels }(r=0.28 ; p=0.01)\end{array}$ & $\begin{array}{c}\text { Concordance } \\
\text { Prognosis }\end{array}$ & [168] \\
\hline
\end{tabular}

\section{Development of a liquid biopsy assay in hematological malignancies to evaluate the response to treatment}

In the field of hematology, studies of liquid biopsy in terms of CTC have been carried out over the last few years, such as in CML (treatment adjustment in terms of $B C R / A B L 1$ peripheral blood leukocyte RNA in CML patients, adjustment in terms of the NPM1-mutated ratio in peripheral blood leukocyte RNA in AML). However, the application of liquid biopsies, in terms of cfDNA, for treatment adjustment (as a biomarker of MRD) in myeloid pathology has not been highly developed. Although, recent publications have shown its usefulness as a complementary technique to CTC or BM study in the follow-up of MRD and allow an interesting genomic representation of the different tumor clones.

There are several papers on the applicability of cfDNA as a marker for MRD in B or $\mathrm{T}$ cell lymphoid malignancies. In these pathologies, there is a lot of information on the usefulness of this approach to evaluate MRD, where it could be considered a new pathway for MRD. In chronic lymphocytic leukemia, the evolution of resistance to treatments in real time could be monitored with ctDNA, and in acute leukemias, it can be helpful in monitoring of early response to treatment and prediction of treatment failure.

References for this review were identified through searches of PUBMED with the search terms "cell free DNA," "liquid biopsy," "MDS," "MPN," "AML," "NHL," "CLL," "MM," and "ALL," published from 1 January 2000 to 31 December 2021. Articles were also identified through searches of the reference authors" names. Only papers published in English were reviewed. The final reference list was generated on the basis of significance and relevance to the broad scope of this review. Note that when we searched for the term cfDNA and cancer, we found 20,446 papers; however, if we associated these terms 
with MRD, only 116 results appeared. If we carried out this specific search for leukemia, lymphoma, or myeloma, four, seven, or seven appeared, respectively. This shows that there are still not many publications with relevant data on the usefulness of liquid biopsies to assess MRD. However, there is great interest in this application and much work is being conducted on different approaches in order to optimize these liquid biopsy techniques to achieve adequate sensitivity for detecting tumor persistence or relapse.

NGS is the preferred method for liquid biopsy studies to detect MRD in hematologic pathology, given the great molecular heterogeneity of these tumors. The main limiting factor of these sequencing tools is the error rate, which varies between $1 \%$ and $0.01 \%$ depending on the sequencing conditions, starting material, and analysis pipeline. Variant detection with high confidence occurs at a fraction below $1 \%$ and therefore requires sufficient depth of coverage (i.e., the number of sequences that "read" any nucleotide position) in both patient and control samples, and the use of bioinformatics analysis as well as algorithms that allow the application of appropriate quality control criteria [31]. In order to optimize this procedure, the main recommendations are as follows.

\subsection{Preanalytical recommendations}

High-quality cfDNA for liquid biopsies is required to avoid contamination by genomic DNA from white blood cells and to maintain sufficient fragment length to allow the conduct of PCR-based methods. Various preanalytical factors can influence samples' quality for ctDNA extraction, such as the centrifugation procedure, or storage conditions. Then, a blood collection tube containing a preservative that stabilizes nucleated blood cells for delayed separation can be used. Recent studies have shown similar ctDNA levels at zero hours or up to five days at room temperature in blood collection tubes with preservative, and $2 \mathrm{~h}$ stability if the blood is drawn in EDTA tubes [177]. A correct centrifugation protocol with the aim of limiting genomic DNA contamination of leukocytes. For cfDNA extraction, the sensitivity of the different assays is driven by a DNA input spin column, and magnetic bead-based isolation methods are influenced by the size of the DNA fragments. Thus, the selected extraction kit must be adapted to the sample, and the use of the membrane-based method promotes the extraction of high molecular weight cfDNA fragments (>600 bp), whereas the magnetic bead system yields shorter cfDNA fragments. Subsequent storage should be at -20 or $-80^{\circ} \mathrm{C}$ for up to nine months with good preservation without thawing or less than three thaws.

\subsection{Advances in NGS}

NGS techniques are rapidly evolving, and their sensitivity is improving, allowing application even in early-stage disease. Various assays are available; PCR-based methods require precise knowledge of the expected alteration and allow the detection of SNV with a very low allele frequency and relatively low time and costs, while NGS-based assays allow the detection of non-hotspot mutations and other variations such as CNV but require more time than PCR assays, a thorough bioinformatics pipeline for analysis, as well as expertise in the technical and complex interpretation of the data read-out.

Basic NGS workflows are designed to detect mutations above a $1 \%$ minimum mutant allele fraction. In ctDNA, this mutant allele fraction is generally reached in a metastatic disease context with a high tumor load. For early-stage cancers, a lower detection threshold is needed for ctDNA mutation detection, and the basic NGS workflow needs further adaptation.

Targeted NGS methods have therefore been developed to screen a large number of potential mutations in tumor biopsies with an elevated sensitivity (e.g., Guardant Health, which employs pre-sequencing preparation of a digital library of individually tagged cfDNA molecules combined with post-sequencing bioinformatic reconstruction to eliminate nearly all false positives; Foundation ACT, with hybrid capture-based assays; CAPP- 
Seq, with limit sequenced regions by capturing recurrently mutated genomic regions; Oncomine Lung cfTNA, with capture-based methods to assess 12 genes that are frequently mutated in lung cancer; Trusight tumor 15 assay, with capture-based methods to assess 15 genes that are frequently mutated in solid tumors; Safe sequencing, with assignment of a unique identifier to each DNA template molecule to be analyzed and amplification of each uniquely tagged template; Archer Reveal cDNA 28kit, with capture-based methods to assess 28 genes that are frequently mutated in solid tumors) [178]. However, there are no specifically targeted NGS methods with an elevated sensitivity oriented to hematological tumors.

\section{Conclusions}

The application of liquid biopsy methods in evaluating the response to treatment of oncohematological pathologies has shown their great utility and could be imposed in a relatively short time, alone or in combination with other methods (e.g., imaging). However, there are still some limitations to overcome, such as improving the obtaining of a sufficient amount of cfDNA and the sensitivity of the techniques used (generally NGS), as well as obtaining validated results in clinical trials.

Author Contributions: Conceptualization, R.C., J.M.L., and R.A.; investigation, N.A. and R.C.; writing - original draft preparation, R.C., N.A., S.B., J.M.L., and R.A., writing - review and editing, R.C., S.B., J.M.L., and R.A.; supervision, J.M.L. and R.A.; funding acquisition, J.M.L. and R.A. All authors read and agreed to the published version of the manuscript.

Funding: This study was supported by the Subdirección General de Investigación Sanitaria (Instituto de Salud Carlos III, Spain), grants PI19/01518, the CRIS against Cancer foundation, grant 2018/001, and by the Instituto de Investigación Hospital 12 de Octubre (IMAS12) (co-financed by FEDER funds).

Informed Consent Statement: Not applicable.

Data Availability Statement: Not applicable.

Conflicts of Interest: J.M-L. declares honoraria for lectures from and membership on advisory boards with Janssen, BMS, Sanofi, Novartis, Incyte, Roche, and Amgen. R.A. declares being an advisory board member for Novartis and Incyte and a speaker honorarium from Astellas, Celgene, and Novartis. S.B. is an employee and S.B., J.M.-L., and R.A. are equity shareholders of Altum Sequencing $\mathrm{Co}$. The remaining authors declare no competing financial interests.

\section{References}

1. Poulet, G.; Massias, J.; Taly, V. Liquid Biopsy: General Concepts. Acta Cytol. 2019, 63, 449-455, doi:10.1159/000499337.

2. Alix-Panabières, C.; Schwarzenbach, H.; Pantel, K. Circulating Tumor Cells and Circulating Tumor DNA. Annu. Rev. Med. 2012, 63, 199-215, doi:10.1146/annurev-med-062310-094219.

3. Siravegna, G.; Marsoni, S.; Siena, S.; Bardelli, A. Integrating Liquid Biopsies into the Management of Cancer. Nat. Rev. Clin. Oncol. 2017, 14, 531-548, doi:10.1038/nrclinonc.2017.14.

4. Chen, L.; Bode, A.M.; Dong, Z. Circulating Tumor Cells: Moving Biological Insights into Detection. Theranostics 2017, 7, 2606-2619, doi:10.7150/thno.18588.

5. Cirillo, M.; Craig, A.F.M.; Borchmann, S.; Kurtz, D.M. Liquid Biopsy in Lymphoma: Molecular Methods and Clinical Applications. Cancer Treat. Rev. 2020, 91, 102106, doi:10.1016/j.ctrv.2020.102106.

6. Mandel, P.; Metais, P. Nuclear Acids In Human Blood Plasma. C. R. Seances Soc. Biol. Fil. 1948, 142, 241-243.

7. Leon, S.A.; Shapiro, B.; Sklaroff, D.M.; Yaros, M.J. Free DNA in the Serum of Cancer Patients and the Effect of Therapy. Cancer Res. 1977, 37, 646-650. 
8. Stroun, M.; Anker, P.; Maurice, P.; Lyautey, J.; Lederrey, C.; Beljanski, M. Neoplastic Characteristics of the DNA Found in the Plasma of Cancer Patients. Oncology 1989, 46, 318-322, doi:10.1159/000226740.

9. Khier, S.; Lohan, L. Kinetics of Circulating Cell-Free DNA for Biomedical Applications: Critical Appraisal of the Literature. Future Sci. OA 2018, 4, FSO295, doi:10.4155/fsoa-2017-0140.

10. Stroun, M.; Lyautey, J.; Lederrey, C.; Olson-Sand, A.; Anker, P. About the Possible Origin and Mechanism of Circulating DNA. Clin. Chim. Acta 2001, 313, 139-142, doi:10.1016/S0009-8981(01)00665-9.

11. van der Vaart, M.; Pretorius, P.J. The Origin of Circulating Free DNA. Clin. Chem. 2007, 53, 2215, doi:10.1373/clinchem.2007.092734.

12. van der Vaart, M.; Pretorius, P.J. Circulating DNA. Its Origin and Fluctuation. Ann. N. Y. Acad. Sci. 2008, 1137, 18-26, doi:10.1196/annals.1448.022.

13. Mouliere, F.; Chandrananda, D.; Piskorz, A.M.; Moore, E.K.; Morris, J.; Ahlborn, L.B.; Mair, R.; Goranova, T.; Marass, F.; Heider, K.; et al. Enhanced Detection of Circulating Tumor DNA by Fragment Size Analysis. Sci. Transl. Med. 2018, 10, eaat4921, doi:10.1126/scitranslmed.aat4921.

14. Jahr, S.; Hentze, H.; Englisch, S.; Hardt, D.; Fackelmayer, F.O.; Hesch, R.D.; Knippers, R. DNA Fragments in the Blood Plasma of Cancer Patients: Quantitations and Evidence for Their Origin from Apoptotic and Necrotic Cells. Cancer Res. 2001, 61, 1659-1665.

15. Corcoran, R.B.; Chabner, B.A. Application of Cell-Free DNA Analysis to Cancer Treatment. N. Engl. J. Med. 2018, 379, 1754-1765, doi:10.1056/NEJMra1706174.

16. Hohaus, S.; Giachelia, M.; Massini, G.; Mansueto, G.; Vannata, B.; Bozzoli, V.; Criscuolo, M.; D’Alò, F.; Martini, M.; Larocca, L.M.; et al. Cell-Free Circulating DNA in Hodgkin's and Non-Hodgkin's Lymphomas. Ann. Oncol. 2009, 20, 1408-1413, doi:10.1093/annonc/mdp006.

17. Salehi, M.; Sharifi, M. Exosomal MiRNAs as Novel Cancer Biomarkers: Challenges and Opportunities. J. Cell. Physiol. 2018, 233, 6370-6380, doi:10.1002/jcp.26481.

18. Leslie, M. Cell Biology. Beyond Clotting: The Powers of Platelets. Science 2010, 328, 562-564, doi:10.1126/science.328.5978.562.

19. Nilsson, R.J.A.; Balaj, L.; Hulleman, E.; van Rijn, S.; Pegtel, D.M.; Walraven, M.; Widmark, A.; Gerritsen, W.R.; Verheul, H.M.; Vandertop, W.P.; et al. Blood Platelets Contain Tumor-Derived RNA Biomarkers. Blood 2011, 118, 3680-3683, doi:10.1182/blood-2011-03-344408.

20. Becker, A.; Thakur, B.K.; Weiss, J.M.; Kim, H.S.; Peinado, H.; Lyden, D. Extracellular Vesicles in Cancer: Cell-to-Cell Mediators of Metastasis. Cancer Cell 2016, 30, 836-848, doi:10.1016/j.ccell.2016.10.009.

21. van Eijndhoven, M.A.; Zijlstra, J.M.; Groenewegen, N.J.; Drees, E.E.; van Niele, S.; Baglio, S.R.; Koppers-Lalic, D.; van der Voorn, H.; Libregts, S.F.; Wauben, M.H.; et al. Plasma Vesicle MiRNAs for Therapy Response Monitoring in Hodgkin Lymphoma Patients. JCI Insight 2016, 1, e89631, doi:10.1172/jci.insight.89631.

22. Diaz, L.A.; Bardelli, A. Liquid Biopsies: Genotyping Circulating Tumor DNA. J. Clin. Oncol. Off. J. Am. Soc. Clin. Oncol. 2014, 32, 579-586, doi:10.1200/JCO.2012.45.2011.

23. Bettegowda, C.; Sausen, M.; Leary, R.J.; Kinde, I.; Wang, Y.; Agrawal, N.; Bartlett, B.R.; Wang, H.; Luber, B.; Alani, R.M.; et al. Detection of Circulating Tumor DNA in Early- and Late-Stage Human Malignancies. Sci. Transl. Med. 2014, 6, 224ra24, doi:10.1126/scitranslmed.3007094.

24. Hindson, C.M.; Chevillet, J.R.; Briggs, H.A.; Gallichotte, E.N.; Ruf, I.K.; Hindson, B.J.; Vessella, R.L.; Tewari, M. Absolute Quantification by Droplet Digital PCR versus Analog Real-Time PCR. Nat. Methods 2013, 10, 1003-1005, doi:10.1038/nmeth.2633. 25. Bratman, S.V.; Newman, A.M.; Alizadeh, A.A.; Diehn, M. Potential Clinical Utility of Ultrasensitive Circulating Tumor DNA Detection with CAPP-Seq. Expert Rev. Mol. Diagn. 2015, 15, 715-719, doi:10.1586/14737159.2015.1019476.

26. Schroeder, T.; Rachlis, E.; Bug, G.; Stelljes, M.; Klein, S.; Steckel, N.K.; Wolf, D.; Ringhoffer, M.; Czibere, A.; Nachtkamp, 
K.; et al. Treatment of Acute Myeloid Leukemia or Myelodysplastic Syndrome Relapse after Allogeneic Stem Cell Transplantation with Azacitidine and Donor Lymphocyte Infusions--a Retrospective Multicenter Analysis from the German Cooperative Transplant Study Group. Biol. Blood Marrow Transplant. J. Am. Soc. Blood Marrow Transplant. 2015, 21, 653-660, doi:10.1016/j.bbmt.2014.12.016.

27. Onecha, E.; Linares, M.; Rapado, I.; Ruiz-Heredia, Y.; Martinez-Sanchez, P.; Cedena, T.; Pratcorona, M.; Oteyza, J.P.; Herrera, P.; Barragan, E.; et al. A Novel Deep Targeted Sequencing Method for Minimal Residual Disease Monitoring in Acute Myeloid Leukemia. Haematologica 2019, 104, 288-296, doi:10.3324/haematol.2018.194712.

28. Onecha, E.; Rapado, I.; Luz Morales, M.; Carreño-Tarragona, G.; Martinez-Sanchez, P.; Gutierrez, X.; Sáchez Pina, J.M.; Linares, M.; Gallardo, M.; Martinez-López, J.; et al. Monitoring of Clonal Evolution of Acute Myeloid Leukemia Identifies the Leukemia Subtype, Clinical Outcome and Potential New Drug Targets for Post-Remission Strategies or Relapse. Haematologica 2021, 106, 2325-2333, doi:10.3324/haematol.2020.254623.

29. Shapiro, R.M.; Kim, D.D.H. Next-Generation Sequencing-Based Minimal Residual Disease Monitoring in Patients Receiving Allogeneic Hematopoietic Stem Cell Transplantation for Acute Myeloid Leukemia or Myelodysplastic Syndrome. Curr. Opin. Hematol. 2018, 25, 425-432, doi:10.1097/MOH.0000000000000464.

30. Platzbecker, U.; Kubasch, A.S.; Homer-Bouthiette, C.; Prebet, T. Current Challenges and Unmet Medical Needs in Myelodysplastic Syndromes. Leukemia 2021, 35, 2182-2198, doi:10.1038/s41375-021-01265-7.

31. Honoré, N.; Galot, R.; van Marcke, C.; Limaye, N.; Machiels, J.-P. Liquid Biopsy to Detect Minimal Residual Disease: Methodology and Impact. Cancers 2021, 13, 5364, doi:10.3390/cancers13215364.

32. Shin, S.; Woo, H.I.; Kim, J.-W.; M D, Y.K.; Lee, K.-A. Clinical Practice Guidelines for Pre-Analytical Procedures of Plasma Epidermal Growth Factor Receptor Variant Testing. Ann. Lab. Med. 2022, 42, 141-149, doi:10.3343/alm.2022.42.2.141.

33. Heuser, M.; Freeman, S.D.; Ossenkoppele, G.J.; Buccisano, F.; Hourigan, C.S.; Ngai, L.L.; Tettero, J.M.; Bachas, C.; Baer, C.; Béné, M.-C.; et al. 2021 Update on MRD in Acute Myeloid Leukemia: A Consensus Document from the European LeukemiaNet MRD Working Party. Blood 2021, 138, 2753-2767, doi:10.1182/blood.2021013626.

34. National Comprehensive Cancer Network Acute Myeloid Leukemia (Version 1.2022); 2022; Retrieved from: https://www.nccn.org/professionals/physician_gls/pdf/aml.pdf

35. National Comprehensive Cancer Network Myelodysplastic Syndromes (Version 3.2022); 2022; Retrieved from: https://www.nccn.org/professionals/physician_gls/pdf/mds.pdf

36. Barosi, G.; Mesa, R.; Finazzi, G.; Harrison, C.; Kiladjian, J.-J.; Lengfelder, E.; McMullin, M.F.; Passamonti, F.; Vannucchi, A.M.; Besses, C.; et al. Revised Response Criteria for Polycythemia Vera and Essential Thrombocythemia: An ELN and IWG-MRT Consensus Project. Blood 2013, 121, 4778-4781, doi:10.1182/blood-2013-01-478891.

37. Tefferi, A.; Cervantes, F.; Mesa, R.; Passamonti, F.; Verstovsek, S.; Vannucchi, A.M.; Gotlib, J.; Dupriez, B.; Pardanani, A.; Harrison, C.; et al. Revised Response Criteria for Myelofibrosis: International Working Group-Myeloproliferative Neoplasms Research and Treatment (IWG-MRT) and European LeukemiaNet (ELN) Consensus Report. Blood 2013, 122, 1395-1398, doi:10.1182/blood-2013-03-488098.

38. National Comprehensive Cancer Network Myeloproliferative Neoplasms (Version 2.2021); 2021; Retrieved from: https://www.nccn.org/professionals/physician_gls/pdf/mpn.pdf

39. National Comprehensive Cancer Network Chronic Myeloid Leukemia (Version 2.2022); 2022; Retrieved from: https://www.nccn.org/professionals/physician_gls/pdf/cml.pdf

40. National Comprehensive Cancer Network Acute Lymphoblastic Leukemia (Version 4.2021); 2021; Retrieved from: https://www.nccn.org/professionals/physician_gls/pdf/cml.pdf

41. National Comprehensive Cancer Network B-Cell Lymphomas (Version 5.2021); 2021; Retrieved from: https://www.nccn.org/professionals/physician_gls/pdf/b-cell.pdf

42. National Comprehensive Cancer Network Hodgkin Lymphoma (Version 1.2022); 2022; Retrieved from: 
https://www.nccn.org/professionals/physician_gls/pdf/hodgkins.pdf

43. National Comprehensive Cancer Network Chronic Lymphocytic Leukemia/Small Lymphocytic Lymphoma (Version 1.2022); 2022; Retrieved from: https://www.nccn.org/professionals/physician_gls/pdf/cll.pdf

44. National Comprehensive Cancer Network Multiple Myeloma (Version 4.2022); 2022; Retrieved from: https://www.nccn.org/professionals/physician_gls/pdf/myeloma.pdf

45. Rowe, J.M. Will New Agents Impact Survival in AML? Best Pract. Res. Clin. Haematol. 2019, 32, 101094, doi:10.1016/j.beha.2019.101094.

46. Pelcovits, A.; Niroula, R. Acute Myeloid Leukemia: A Review. R I Med J. 2013, 3, 38-40.

47. De Kouchkovsky, I.; Abdul-Hay, M. ‘Acute Myeloid Leukemia: A Comprehensive Review and 2016 Update.' Blood Cancer J. 2016, 6, e441-e441, doi:10.1038/bcj.2016.50.

48. Döhner, H.; Weisdorf, D.J.; Bloomfield, C.D. Acute Myeloid Leukemia. N. Engl. J. Med. 2015, 373, 1136-1152, doi:10.1056/NEJMra1406184.

49. Fitzmaurice, C.; Global Burden of Disease Cancer Collaboration Global, Regional, and National Cancer Incidence, Mortality, Years of Life Lost, Years Lived with Disability, and Disability-Adjusted Life-Years for 29 Cancer Groups, 2006 to 2016 : A Systematic Analysis for the Global Burden of Disease Study. J. Clin. Oncol. 2018, 36, 1568-1568, doi:10.1200/JCO.2018.36.15_suppl.1568.

50. Narayanan, D.; Weinberg, O.K. How I Investigate Acute Myeloid Leukemia. Int. J. Lab. Hematol. 2020, 42, 3-15, doi:10.1111/ijlh.13135.

51. Pettersson, L.; Levéen, P.; Axler, O.; Dvorakova, D.; Juliusson, G.; Ehinger, M. Improved Minimal Residual Disease Detection by Targeted Quantitative Polymerase Chain Reaction in Nucleophosmin 1 Type a Mutated Acute Myeloid Leukemia: MFC vs. RQ-PCR in MRD Detection in AML. Genes. Chromosomes Cancer 2016, 55, 750-766, doi:10.1002/gcc.22375.

52. Handschuh, L.; Kaźmierczak, M.; Milewski, M.; Goralski, M.; Luczak, M.; Wojtaszewska, M.; Uszczyńska-Ratajczak, B.; Lewandowski, K.; Komarnicki, M.; Figlerowicz, M. Gene Expression Profiling of Acute Myeloid Leukemia Samples from Adult Patients with AML-M1 and -M2 through Boutique Microarrays, Real-Time PCR and Droplet Digital PCR. Int. J. Oncol. 2017, doi:10.3892/ijo.2017.4233.

53. Grassi, S.; Guerrini, F.; Ciabatti, E.; Puccetti, R.; Salehzadeh, S.; Metelli, M.R.; Di Vita, A.; Domenichini, C.; Caracciolo, F.; Orciuolo, E.; et al. Digital Droplet PCR Is a Specific and Sensitive Tool for Detecting IDH2 Mutations in Acute Myeloid LeuKemia Patients. Cancers 2020, 12, 1738, doi:10.3390/cancers12071738.

54. Maurillo, L.; Buccisano, F.; Spagnoli, A.; Del Poeta, G.; Panetta, P.; Neri, B.; Del Principe, M.I.; Mazzone, C.; Consalvo, M.I.; Tamburini, A.; et al. Monitoring of Minimal Residual Disease in Adult Acute Myeloid Leukemia Using Peripheral Blood as an Alternative Source to Bone Marrow. Haematologica 2007, 92, 605-611, doi:10.3324/haematol.10432.

55. Buccisano, F.; Maurillo, L.; Gattei, V.; Del Poeta, G.; Del Principe, M.I.; Cox, M.C.; Panetta, P.; Consalvo, M.I.; Mazzone, C.; Neri, B.; et al. The Kinetics of Reduction of Minimal Residual Disease Impacts on Duration of Response and Survival of Patients with Acute Myeloid Leukemia. Leukemia 2006, 20, 1783-1789, doi:10.1038/sj.leu.2404313.

56. Smith, L.-L.; Pearce, D.; Smith, M.L.; Jenner, M.; Andrew Lister, T.; Bonnet, D.; Goff, L.; Fitzgibbon, J. Development of a Quantitative Real-Time Polymerase Chain Reaction Method for Monitoring CEBPA Mutations in Normal Karyotype Acute Myeloid Leukaemia. Br. J. Haematol. 2006, 0, 060203080756008, doi:10.1111/j.1365-2141.2006.06001.x.

57. Kern, W.; Bacher, U.; Haferlach, C.; Schnittger, S.; Haferlach, T. The Role of Multiparameter Flow Cytometry for Disease Monitoring in AML. Best Pract. Res. Clin. Haematol. 2010, 23, 379-390, doi:10.1016/j.beha.2010.06.007.

58. Cruz, N.M.; Mencia-Trinchant, N.; Hassane, D.C.; Guzman, M.L. Minimal Residual Disease in Acute Myelogenous Leukemia. Int. J. Lab. Hematol. 2017, 39, 53-60, doi:10.1111/ijlh.12670.

59. Zeijlemaker, W.; Kelder, A.; Oussoren-Brockhoff, Y.J.M.; Scholten, W.J.; Snel, A.N.; Veldhuizen, D.; Cloos, J.; Ossenkoppele, G.J.; Schuurhuis, G.J. Peripheral Blood Minimal Residual Disease May Replace Bone Marrow Minimal Residual 
Disease as an Immunophenotypic Biomarker for Impending Relapse in Acute Myeloid Leukemia. Leukemia 2016, 30, 708-715, doi:10.1038/leu.2015.255.

60. Pettersson, L.; Levéen, P.; Axler, O.; Dvorakova, D.; Juliusson, G.; Ehinger, M. Improved Minimal Residual Disease Detection by Targeted Quantitative Polymerase Chain Reaction in Nucleophosmin 1 Type a Mutated Acute Myeloid Leukemia: MFC vs. RQ-PCR in MRD Detection in AML. Genes. Chromosomes Cancer 2016, 55, 750-766, doi:10.1002/gcc.22375.

61. Handschuh, L.; Kaźmierczak, M.; Milewski, M.; Gï ¿²/2ralski, M.; Łuczak, M.; Wojtaszewska, M.; Uszczyńska-Ratajczak, B.; Lewandowski, K.; Komarnicki, M.; Figlerowicz, M. Gene Expression Profiling of Acute Myeloid Leukemia Samples from Adult Patients with AML-M1 and -M2 through Boutique Microarrays, Real-Time PCR and Droplet Digital PCR. Int. J. Oncol. 2017, doi:10.3892/ijo.2017.4233.

62. Thol, F.; Kölking, B.; Damm, F.; Reinhardt, K.; Klusmann, J.-H.; Reinhardt, D.; von Neuhoff, N.; Brugman, M.H.; Schlegelberger, B.; Suerbaum, S.; et al. Next-Generation Sequencing for Minimal Residual Disease Monitoring in Acute Myeloid Leukemia Patients with FLT3-ITD or NPM1 Mutations. Genes. Chromosomes Cancer 2012, 51, 689-695, doi:10.1002/gcc.21955. 63. Vonk, C.M.; Al Hinai, A.S.A.; Hanekamp, D.; Valk, P.J.M. Molecular Minimal Residual Disease Detection in Acute Myeloid Leukemia. Cancers 2021, 13, 5431, doi:10.3390/cancers13215431.

64. Grimwade, D.; Freeman, S.D. Defining Minimal Residual Disease in Acute Myeloid Leukemia: Which Platforms Are Ready for "Prime Time"? Hematol. Am. Soc. Hematol. Educ. Program 2014, 2014, 222-233, doi:10.1182/asheducation-2014.1.222.

65. Shumilov, E.; Flach, J.; Kohlmann, A.; Banz, Y.; Bonadies, N.; Fiedler, M.; Pabst, T.; Bacher, U. Current Status and Trends in the Diagnostics of AML and MDS. Blood Rev. 2018, 32, 508-519, doi:10.1016/j.blre.2018.04.008.

66. Haferlach, T. Advancing Leukemia Diagnostics: Role of Next Generation Sequencing (NGS) in Acute Myeloid Leukemia. Hematol. Rep. 2020, 12, 8957, doi:10.4081/hr.2020.8957.

67. Flach, J.; Shumilov, E.; Joncourt, R.; Porret, N.; Novak, U.; Pabst, T.; Bacher, U. Current Concepts and Future Directions for Hemato-Oncologic Diagnostics. Crit. Rev. Oncol. Hematol. 2020, 151, 102977, doi:10.1016/j.critrevonc.2020.102977.

68. Chen, M.; Zhao, H. Next-Generation Sequencing in Liquid Biopsy: Cancer Screening and Early Detection. Hum. Genomics 2019, 13, 34, doi:10.1186/s40246-019-0220-8.

69. Short, N.J.; Patel, K.P.; Albitar, M.; Franquiz, M.; Luthra, R.; Kanagal-Shamanna, R.; Wang, F.; Assi, R.; Montalban-Bravo, G.; Matthews, J.; et al. Targeted Next-Generation Sequencing of Circulating Cell-Free DNA vs Bone Marrow in Patients with Acute Myeloid Leukemia. Blood Adv. 2020, 4, 1670-1677, doi:10.1182/bloodadvances.2019001156.

70. Nakamura, S.; Yokoyama, K.; Shimizu, E.; Yusa, N.; Kondoh, K.; Ogawa, M.; Takei, T.; Kobayashi, A.; Ito, M.; Isobe, M.; et al. Prognostic Impact of Circulating Tumor DNA Status Post-Allogeneic Hematopoietic Stem Cell Transplantation in AML and MDS. Blood 2019, 133, 2682-2695, doi:10.1182/blood-2018-10-880690.

71. Rausch, C.; Rothenberg-Thurley, M.; Buerger, S.A.; Tschuri, S.; Dufour, A.; Neusser, M.; Schneider, S.; Spiekermann, K.; Metzeler, K.H.; Ziemann, F. Double Drop-Off Droplet Digital PCR. J. Mol. Diagn. 2021, 23, 975-985, doi:10.1016/j.jmoldx.2021.05.001.

72. Short, N.J.; Patel, K.P.; Albitar, M.; Franquiz, M.; Luthra, R.; Kanagal-Shamanna, R.; Wang, F.; Assi, R.; Montalban-Bravo, G.; Matthews, J.; et al. Targeted Next-Generation Sequencing of Circulating Cell-Free DNA vs Bone Marrow in Patients with Acute Myeloid Leukemia. Blood Adv. 2020, 4, 1670-1677, doi:10.1182/bloodadvances.2019001156.

73. Lim, J.K.; Kuss, B.; Talaulikar, D. Role of Cell-Free DNA in Haematological Malignancies. Pathology (Phila.) 2021, 53, 416-426, doi:10.1016/j.pathol.2021.01.004.

74. Steensma, D.P. Clinical Implications of Clonal Hematopoiesis. Mayo Clin. Proc. 2018, 93, 1122-1130, doi:10.1016/j.mayocp.2018.04.002.

75. Hasserjian, R.P.; Steensma, D.P.; Graubert, T.A.; Ebert, B.L. Clonal Hematopoiesis and Measurable Residual Disease Assessment in Acute Myeloid Leukemia. Blood 2020, 135, 1729-1738, doi:10.1182/blood.2019004770.

76. Yeh, P.; Dickinson, M.; Ftouni, S.; Hunter, T.; Sinha, D.; Wong, S.Q.; Agarwal, R.; Vedururu, R.; Doig, K.; Fong, C.Y.; et 
al. Molecular Disease Monitoring Using Circulating Tumor DNA in Myelodysplastic Syndromes. Blood 2017, 129, 1685-1690, doi:10.1182/blood-2016-09-740308.

77. Gutierrez-Rodrigues, F.; Beerman, I.; Groarke, E.M.; Patel, B.A.; Spitofsky, N.; Dillon, L.W.; Raffo, D.Q.; Hourigan, C.S.; Kajigaya, S.; Ferrucci, L.; et al. Utility of Plasma Cell-Free DNA for de Novo Detection and Quantification of Clonal Hematopoiesis. Haematologica 2021, doi:10.3324/haematol.2021.279230.

78. Arber, D.A.; Orazi, A.; Hasserjian, R.; Thiele, J.; Borowitz, M.J.; Le Beau, M.M.; Bloomfield, C.D.; Cazzola, M.; Vardiman, J.W. The 2016 Revision to the World Health Organization Classification of Myeloid Neoplasms and Acute Leukemia. Blood 2016, 127, 2391-2405, doi:10.1182/blood-2016-03-643544.

79. Barbui, T.; Thiele, J.; Gisslinger, H.; Kvasnicka, H.M.; Vannucchi, A.M.; Guglielmelli, P.; Orazi, A.; Tefferi, A. The 2016 WHO Classification and Diagnostic Criteria for Myeloproliferative Neoplasms: Document Summary and in-Depth Discussion. Blood Cancer J. 2018, 8, 15, doi:10.1038/s41408-018-0054-y.

80. Tefferi, A.; Barbui, T. Polycythemia Vera and Essential Thrombocythemia: 2021 Update on Diagnosis, Risk-stratification and Management. Am. J. Hematol. 2020, 95, 1599-1613, doi:10.1002/ajh.26008.

81. Garcia-Gisbert, N.; Fernández-Ibarrondo, L.; Fernández-Rodríguez, C.; Gibert, J.; Andrade-Campos, M.; Arenillas, L.; Camacho, L.; Angona, A.; Longarón, R.; Salar, A.; et al. Circulating Cell-Free DNA Improves the Molecular Characterisation of Ph-Negative Myeloproliferative Neoplasms. Br. J. Haematol. 2021, 192, 300-309, doi:10.1111/bjh.17087.

82. Redaelli, A.; Laskin, B.L.; Stephens, J.M.; Botteman, M.F.; Pashos, C.L. A Systematic Literature Review of the Clinical and Epidemiological Burden of Acute Lymphoblastic Leukaemia (ALL). Eur. J. Cancer Care (Engl.) 2005, 14, 53-62, doi:10.1111/j.1365-2354.2005.00513.x.

83. Nunes, V.; Cazzaniga, G.; Biondi, A. An Update on PCR Use for Minimal Residual Disease Monitoring in Acute Lymphoblastic Leukemia. Expert Rev. Mol. Diagn. 2017, 17, 953-963, doi:10.1080/14737159.2017.1377073.

84. Theunissen, P.; Mejstrikova, E.; Sedek, L.; van der Sluijs-Gelling, A.J.; Gaipa, G.; Bartels, M.; Sobral da Costa, E.; Kotrová, M.; Novakova, M.; Sonneveld, E.; et al. Standardized Flow Cytometry for Highly Sensitive MRD Measurements in B-Cell Acute Lymphoblastic Leukemia. Blood 2017, 129, 347-357, doi:10.1182/blood-2016-07-726307.

85. Kruse, A.; Abdel-Azim, N.; Kim, H.N.; Ruan, Y.; Phan, V.; Ogana, H.; Wang, W.; Lee, R.; Gang, E.J.; Khazal, S.; et al. Minimal Residual Disease Detection in Acute Lymphoblastic Leukemia. Int. J. Mol. Sci. 2020, 21, E1054, doi:10.3390/ijms21031054.

86. Kotrova, M.; Muzikova, K.; Mejstrikova, E.; Novakova, M.; Bakardjieva-Mihaylova, V.; Fiser, K.; Stuchly, J.; Giraud, M.; Salson, M.; Pott, C.; et al. The Predictive Strength of Next-Generation Sequencing MRD Detection for Relapse Compared with Current Methods in Childhood ALL. Blood 2015, 126, 1045-1047, doi:10.1182/blood-2015-07-655159.

87. Muffly, L.; Sundaram, V.; Chen, C.; Yurkiewicz, I.; Kuo, E.; Burnash, S.; Spiegel, J.Y.; Arai, S.; Frank, M.J.; Johnston, L.J.; et al. Concordance of Peripheral Blood and Bone Marrow Measurable Residual Disease in Adult Acute Lymphoblastic Leukemia. Blood Adv. 2021, 5, 3147-3151, doi:10.1182/bloodadvances.2021004234.

88. van der Velden, V.H.J.; Jacobs, D.C.H.; Wijkhuijs, A.J.M.; Comans-Bitter, W.M.; Willemse, M.J.; Hählen, K.; Kamps, W.A.; van Wering, E.R.; van Dongen, J.J.M. Minimal Residual Disease Levels in Bone Marrow and Peripheral Blood Are Comparable in Children with T Cell Acute Lymphoblastic Leukemia (ALL), but Not in Precursor-B-ALL. Leukemia 2002, 16, 1432-1436, doi:10.1038/sj.leu.2402636.

89. Schwarz, A.K.; Stanulla, M.; Cario, G.; Flohr, T.; Sutton, R.; Möricke, A.; Anker, P.; Stroun, M.; Welte, K.; Bartram, C.R.; et al. Quantification of Free Total Plasma DNA and Minimal Residual Disease Detection in the Plasma of Children with Acute Lymphoblastic Leukemia. Ann. Hematol. 2009, 88, 897-905, doi:10.1007/s00277-009-0698-6.

90. Cheng, S.H.; Lau, K.M.; Li, C.K.; Chan, N.P.H.; Ip, R.K.L.; Cheng, C.K.; Lee, V.; Shing, M.M.K.; Leung, A.W.K.; Ha, S.Y.; et al. Minimal Residual Disease-Based Risk Stratification in Chinese Childhood Acute Lymphoblastic Leukemia by Flow Cytometry and Plasma DNA Quantitative Polymerase Chain Reaction. PloS One 2013, 8, e69467, 
doi:10.1371/journal.pone.0069467.

91. Yegin, Z.A.; Can, F.; Gökçen, S.; Sadioğlu, R.E.; Özkurt, Z.N.; İlhan, Ç.; Yağcı, M. The Impact of Pre-Transplant Cell-Free DNA Levels on Leukemia Relapse and Transplant-Related Complications in Allogeneic Hematopoietic Stem Cell Transplant Recipients. Balk. Med. J. 2020, 37, 138-143, doi:10.4274/balkanmedj.galenos.2020.2019.8.25.

92. Camus, V.; Jardin, F. Cell-Free DNA for the Management of Classical Hodgkin Lymphoma. Pharm. Basel Switz. 2021, 14, 207, doi:10.3390/ph14030207.

93. Schürch, C.M.; Federmann, B.; Quintanilla-Martinez, L.; Fend, F. Tumor Heterogeneity in Lymphomas: A Different Breed. Pathobiology 2018, 85, 130-145, doi:10.1159/000475530.

94. Melani, C.; Wilson, W.H.; Roschewski, M. Monitoring Clinical Outcomes in Aggressive B-Cell Lymphoma: From Imaging Studies to Circulating Tumor DNA. Best Pract. Res. Clin. Haematol. 2018, 31, 285-292, doi:10.1016/j.beha.2018.07.004.

95. Camus, V.; Jardin, F.; Tilly, H. The Value of Liquid Biopsy in Diagnosis and Monitoring of Diffuse Large B-Cell Lymphoma: Recent Developments and Future Potential. Expert Rev. Mol. Diagn. 2017, 17, 557-566, doi:10.1080/14737159.2017.1319765.

96. Li, M.; Xu, C. Circulating Cell-Free DNA Utility for the Surveillance of Patients with Treated Diffuse Large B-Cell Lymphoma. Clin. Oncol. R. Coll. Radiol. G. B. 2017, 29, 637-638, doi:10.1016/j.clon.2017.03.008.

97. Eskandari, M.; Manoochehrabadi, S.; Pashaiefar, H.; Zaimy, M.A.; Ahmadvand, M. Clinical Significance of Cell-Free DNA as a Prognostic Biomarker in Patients with Diffuse Large B-Cell Lymphoma. Blood Res. 2019, 54, 114-119, doi:10.5045/br.2019.54.2.114.

98. Hur, J.Y.; Kim, Y.J.; Yoon, S.E.; Son, D.-S.; Park, W.-Y.; Kim, S.J.; Park, D.; Kim, W.S. Plasma Cell-Free DNA Is a Prognostic Biomarker for Survival in Patients with Aggressive Non-Hodgkin Lymphomas. Ann. Hematol. 2020, 99, 1293-1302, doi:10.1007/s00277-020-04008-3.

99. Lv, L.; Liu, Y. Clinical Application of Liquid Biopsy in Non-Hodgkin Lymphoma. Front. Oncol. 2021, 11, 658234, doi:10.3389/fonc. 2021.658234 .

100. Armand, P.; Oki, Y.; Neuberg, D.S.; Faham, M.; Cummings, C.; Klinger, M.; Weng, L.; Bhattar, S.; Lacasce, A.S.; Jacobsen, E.D.; et al. Detection of Circulating Tumour DNA in Patients with Aggressive B-Cell Non-Hodgkin Lymphoma. Br. J. Haematol. 2013, 163, 123-126, doi:10.1111/bjh.12439.

101. Kurtz, D.M.; Green, M.R.; Bratman, S.V.; Scherer, F.; Liu, C.L.; Kunder, C.A.; Takahashi, K.; Glover, C.; Keane, C.; Kihira, S.; et al. Noninvasive Monitoring of Diffuse Large B-Cell Lymphoma by Immunoglobulin High-Throughput Sequencing. Blood 2015, 125, 3679-3687, doi:10.1182/blood-2015-03-635169.

102. Roschewski, M.; Dunleavy, K.; Pittaluga, S.; Moorhead, M.; Pepin, F.; Kong, K.; Shovlin, M.; Jaffe, E.S.; Staudt, L.M.; Lai, C.; et al. Circulating Tumour DNA and CT Monitoring in Patients with Untreated Diffuse Large B-Cell Lymphoma: A Correlative Biomarker Study. Lancet Oncol. 2015, 16, 541-549, doi:10.1016/S1470-2045(15)70106-3.

103. Herrera, A.F.; Kim, H.T.; Kong, K.A.; Faham, M.; Sun, H.; Sohani, A.R.; Alyea, E.P.; Carlton, V.E.; Chen, Y.-B.; Cutler, C.S.; et al. Next-Generation Sequencing-Based Detection of Circulating Tumour DNA After Allogeneic Stem Cell Transplantation for Lymphoma. Br. J. Haematol. 2016, 175, 841-850, doi:10.1111/bjh.14311.

104. Camus, V.; Jardin, F. Cell-Free DNA and the Monitoring of Lymphoma Treatment. Pharmacogenomics 2019, 20, 12711282, doi:10.2217/pgs-2019-0099.

105. Li, M.; Jia, Y.; Xu, J.; Cheng, X.; Xu, C. Assessment of the Circulating Cell-Free DNA Marker Association with Diagnosis and Prognostic Prediction in Patients with Lymphoma: A Single-Center Experience. Ann. Hematol. 2017, 96, 1343-1351, doi:10.1007/s00277-017-3043-5.

106. Rossi, D.; Diop, F.; Spaccarotella, E.; Monti, S.; Zanni, M.; Rasi, S.; Deambrogi, C.; Spina, V.; Bruscaggin, A.; Favini, C.; et al. Diffuse Large B-Cell Lymphoma Genotyping on the Liquid Biopsy. Blood 2017, 129, 1947-1957, doi:10.1182/blood-201605-719641.

107. Kurtz, D.M.; Scherer, F.; Jin, M.C.; Soo, J.; Craig, A.F.M.; Esfahani, M.S.; Chabon, J.J.; Stehr, H.; Liu, C.L.; Tibshirani, R.; 
et al. Circulating Tumor DNA Measurements As Early Outcome Predictors in Diffuse Large B-Cell Lymphoma. J. Clin. Oncol. 2018, 36, 2845-2853, doi:10.1200/JCO.2018.78.5246.

108. Rivas-Delgado, A.; Nadeu, F.; Enjuanes, A.; Casanueva-Eliceiry, S.; Mozas, P.; Magnano, L.; Castrejón de Anta, N.; Rovira, J.; Dlouhy, I.; Martín, S.; et al. Mutational Landscape and Tumor Burden Assessed by Cell-Free DNA in Diffuse Large B-Cell Lymphoma in a Population-Based Study. Clin. Cancer Res. Off. J. Am. Assoc. Cancer Res. 2021, 27, 513-521, doi:10.1158/10780432.CCR-20-2558.

109. Kurtz, D.M.; Soo, J.; Co Ting Keh, L.; Alig, S.; Chabon, J.J.; Sworder, B.J.; Schultz, A.; Jin, M.C.; Scherer, F.; Garofalo, A.; et al. Enhanced Detection of Minimal Residual Disease by Targeted Sequencing of Phased Variants in Circulating Tumor DNA. Nat. Biotechnol. 2021, doi:10.1038/s41587-021-00981-w.

110. Scherer, F.; Kurtz, D.M.; Newman, A.M.; Stehr, H.; Craig, A.F.M.; Esfahani, M.S.; Lovejoy, A.F.; Chabon, J.J.; Klass, D.M.; Liu, C.L.; et al. Distinct Biological Subtypes and Patterns of Genome Evolution in Lymphoma Revealed by Circulating Tumor DNA. Sci. Transl. Med. 2016, 8, doi:10.1126/scitranslmed.aai8545.

111. Arzuaga-Mendez, J.; Prieto-Fernández, E.; Lopez-Lopez, E.; Martin-Guerrero, I.; García-Ruiz, J.C.; García-Orad, A. CellFree DNA as a Biomarker in Diffuse Large B-Cell Lymphoma: A Systematic Review. Crit. Rev. Oncol. Hematol. 2019, 139, 7-15, doi:10.1016/j.critrevonc.2019.04.013.

112. Chen, F.; Pang, D.; Guo, H.; Jiang, X.; Liu, S.; Huang, L.; Wei, X.; Liang, Z.; Wang, X.; Li, W. Clinicopathological Characteristics and Mutational Profiling of Adult T-Cell Lymphoblastic Lymphoma in a Chinese Population. Cancer Manag. Res. 2020, Volume 12, 3003-3012, doi:10.2147/CMAR.S242903.

113. Shin, S.-H.; Kim, Y.J.; Lee, D.; Cho, D.; Ko, Y.H.; Cho, J.; Park, W.-Y.; Park, D.; Kim, S.J.; Kim, W.S. Analysis of Circulating Tumor DNA by Targeted Ultra-Deep Sequencing across Various Non-Hodgkin Lymphoma Subtypes. Leuk. Lymphoma 2019, 60, 2237-2246, doi:10.1080/10428194.2019.1573998.

114. Suehara, Y.; Sakata-Yanagimoto, M.; Hattori, K.; Kusakabe, M.; Nanmoku, T.; Sato, T.; Noguchi, M.; Chiba, S. Mutations Found in Cell-free DNA s of Patients with Malignant Lymphoma at Remission Can Derive from Clonal Hematopoiesis. Cancer Sci. 2019, 110, 3375-3381, doi:10.1111/cas.14176.

115. Hossain, N.M.; Dahiya, S.; Le, R.; Abramian, A.M.; Kong, K.A.; Muffly, L.S.; Miklos, D.B. Circulating Tumor DNA Assessment in Patients with Diffuse Large B-Cell Lymphoma Following CAR T-Cell Therapy. Leuk. Lymphoma 2019, 60, 503506, doi:10.1080/10428194.2018.1474463.

116. Galimberti, S.; Genuardi, E.; Mazziotta, F.; Iovino, L.; Morabito, F.; Grassi, S.; Ciabatti, E.; Guerrini, F.; Petrini, M. The Minimal Residual Disease in Non-Hodgkin's Lymphomas: From the Laboratory to the Clinical Practice. Front. Oncol. 2019, 9, 528, doi:10.3389/fonc.2019.00528.

117. Cowan, A.J.; Stevenson, P.A.; Cassaday, R.D.; Graf, S.A.; Fromm, J.R.; Wu, D.; Holmberg, L.A.; Till, B.G.; Chauncey, T.R.; Smith, S.D.; et al. Pretransplantation Minimal Residual Disease Predicts Survival in Patients with Mantle Cell Lymphoma Undergoing Autologous Stem Cell Transplantation in Complete Remission. Biol. Blood Marrow Transplant. 2016, 22, 380-385, doi:10.1016/j.bbmt.2015.08.035.

118. Kolstad, A.; Pedersen, L.B.; Eskelund, C.W.; Husby, S.; Grønbæk, K.; Jerkeman, M.; Laurell, A.; Räty, R.; Elonen, E.; Andersen, N.S.; et al. Molecular Monitoring after Autologous Stem Cell Transplantation and Preemptive Rituximab Treatment of Molecular Relapse; Results from the Nordic Mantle Cell Lymphoma Studies (MCL2 and MCL3) with Median Follow-Up of 8.5 Years. Biol. Blood Marrow Transplant. 2017, 23, 428-435, doi:10.1016/j.bbmt.2016.12.634.

119. Jung, D.; Jain, P.; Yao, Y.; Wang, M. Advances in the Assessment of Minimal Residual Disease in Mantle Cell Lymphoma. J. Hematol. Oncol.J Hematol Oncol 2020, 13, 127, doi:10.1186/s13045-020-00961-8.

120. Lakhotia, R.; Melani, C.; Pittaluga, S.; Dunleavy, K.; Saba, N.S.; Lucas, A.N.; Jacob, A.; Yusko, E.; Steinberg, S.M.; Jaffe, E.S.; et al. Circulating Tumor DNA Dynamics during Therapy Predict Outcomes in Mantle Cell Lymphoma. Blood 2018, 132, 147147, doi:10.1182/blood-2018-99-112573. 
121. Agarwal, R.; Chan, Y.-C.; Tam, C.S.; Hunter, T.; Vassiliadis, D.; Teh, C.E.; Thijssen, R.; Yeh, P.; Wong, S.Q.; Ftouni, S.; et al. Dynamic Molecular Monitoring Reveals That SWI-SNF Mutations Mediate Resistance to Ibrutinib plus Venetoclax in Mantle Cell Lymphoma. Nat. Med. 2019, 25, 119-129, doi:10.1038/s41591-018-0243-z.

122. Bachy, E.; Houot, R.; Morschhauser, F.; Sonet, A.; Brice, P.; Belhadj, K.; Cartron, G.; Audhuy, B.; Fermé, C.; Feugier, P.; et al. Long-Term Follow up of the FL2000 Study Comparing CHVP-Interferon to CHVP-Interferon plus Rituximab in Follicular Lymphoma. Haematologica 2013, 98, 1107-1114, doi:10.3324/haematol.2012.082412.

123. Sarkozy, C.; Huet, S.; Carlton, V.E.H.; Fabiani, B.; Delmer, A.; Jardin, F.; Delfau-Larue, M.-H.; Hacini, M.; Ribrag, V.; Guidez, S.; et al. The Prognostic Value of Clonal Heterogeneity and Quantitative Assessment of Plasma Circulating Clonal IG-VDJ Sequences at Diagnosis in Patients with Follicular Lymphoma. Oncotarget 2017, 8, 8765-8774, doi:10.18632/oncotarget.14448.

124. Delfau-Larue, M.-H.; van der Gucht, A.; Dupuis, J.; Jais, J.-P.; Nel, I.; Beldi-Ferchiou, A.; Hamdane, S.; Benmaad, I.; Laboure, G.; Verret, B.; et al. Total Metabolic Tumor Volume, Circulating Tumor Cells, Cell-Free DNA: Distinct Prognostic Value in Follicular Lymphoma. Blood Adv. 2018, 2, 807-816, doi:10.1182/bloodadvances.2017015164.

125. Jimenez Ubieto, A.I.; Heredia, Y.; de la Rosa, J.M.; Rodriguez Izquierdo, A.; Rufian, L.; Carrillo, J.; Sanchez, R.; Onecha, E.; Chongwu, W.; Sarandeses, P.; et al. 62nd ASH Annual Meeting and Exposition. 2020,.

126. Zeremski, V.; Koehler, M.; Fischer, T.; Schalk, E. Characteristics and Outcome of Patients with Primary CNS Lymphoma in a "Real-Life" Setting Compared to a Clinical Trial. Ann. Hematol. 2016, 95, 793-799, doi:10.1007/s00277-016-2602-5.

127. Hattori, K.; Sakata-Yanagimoto, M.; Suehara, Y.; Yokoyama, Y.; Kato, T.; Kurita, N.; Nishikii, H.; Obara, N.; Takano, S.; Ishikawa, E.; et al. Clinical Significance of Disease-Specific MYD88 Mutations in Circulating DNA in Primary Central Nervous System Lymphoma. Cancer Sci. 2018, 109, 225-230, doi:10.1111/cas.13450.

128. Yoon, S.E.; Kim, Y.J.; Shim, J.H.; Park, D.; Cho, J.; Ko, Y.H.; Park, W.-Y.; Mun, Y.-C.; Lee, K.E.; Cho, D.; et al. Plasma Circulating Tumor DNA in Patients with Primary Central Nervous System Lymphoma. Cancer Res. Treat. 2021, doi:10.4143/crt.2021.752.

129. Hiemcke-Jiwa, L.S.; Leguit, R.J.; Snijders, T.J.; Bromberg, J.E.C.; Nierkens, S.; Jiwa, N.M.; Minnema, M.C.; Huibers, M.M.H. MYD88 p.(L265P) Detection on Cell-Free DNA in Liquid Biopsies of Patients with Primary Central Nervous System Lymphoma. Br. J. Haematol. 2019, 185, 974-977, doi:10.1111/bjh.15674.

130. Rimelen, V.; Ahle, G.; Pencreach, E.; Zinniger, N.; Debliquis, A.; Zalmaï, L.; Harzallah, I.; Hurstel, R.; Alamome, I.; Lamy, F.; et al. Tumor Cell-Free DNA Detection in CSF for Primary CNS Lymphoma Diagnosis. Acta Neuropathol. Commun. 2019, 7 , 43, doi:10.1186/s40478-019-0692-8.

131. Yamagishi, Y.; Sasaki, N.; Nakano, Y.; Matushita, Y.; Omura, T.; Shimizu, S.; Saito, K.; Kobayashi, K.; Narita, Y.; Kondo, A.; et al. Liquid Biopsy of Cerebrospinal Fluid for MYD88 L265P Mutation Is Useful for Diagnosis of Central Nervous System Lymphoma. Cancer Sci. 2021, doi:10.1111/cas.15133.

132. Hayashida, M.; Maekawa, F.; Chagi, Y.; Iioka, F.; Kobashi, Y.; Watanabe, M.; Ohno, H. Combination of Multicolor Flow Cytometry for Circulating Lymphoma Cells and Tests for the RHOAG17V and IDH2R172 Hot-Spot Mutations in Plasma Cell-Free DNA as Liquid Biopsy for the Diagnosis of Angioimmunoblastic T-Cell Lymphoma. Leuk. Lymphoma 2020, 61, 2389-2398, doi:10.1080/10428194.2020.1768382.

133. Miljkovic, M.D.; Melani, C.; Pittaluga, S.; Lakhotia, R.; Lucas, N.; Jacob, A.; Yusko, E.; Jaffe, E.S.; Wilson, W.H.; Roschewski, M. Next-Generation Sequencing-Based Monitoring of Circulating Tumor DNA Reveals Clonotypic Heterogeneity in Untreated PTCL. Blood Adv. 2021, 5, 4198-4210, doi:10.1182/bloodadvances.2020003679.

134. Diehl, V.; Thomas, R.K.; Re, D. Part II: Hodgkin's Lymphoma--Diagnosis and Treatment. Lancet Oncol. 2004, 5, 19-26, doi:10.1016/s1470-2045(03)01320-2.

135. Bessi, L.; Viailly, P.-J.; Bohers, E.; Ruminy, P.; Maingonnat, C.; Bertrand, P.; Vasseur, N.; Beaussire, L.; Cornic, M.; Etancelin, P.; et al. Somatic Mutations of Cell-Free Circulating DNA Detected by Targeted next-Generation Sequencing and Digital Droplet PCR in Classical Hodgkin Lymphoma. Leuk. Lymphoma 2019, 60, 498-502, doi:10.1080/10428194.2018.1492123. 
136. Camus, V.; Viennot, M.; Lequesne, J.; Viailly, P.-J.; Bohers, E.; Bessi, L.; Marcq, B.; Etancelin, P.; Dubois, S.; Picquenot, J.-M.; et al. Targeted Genotyping of Circulating Tumor DNA for Classical Hodgkin Lymphoma Monitoring: A Prospective Study. Haematologica 2021, 106, 154-162, doi:10.3324/haematol.2019.237719.

137. Spina, V.; Bruscaggin, A.; Cuccaro, A.; Martini, M.; Di Trani, M.; Forestieri, G.; Manzoni, M.; Condoluci, A.; Arribas, A.; Terzi-Di-Bergamo, L.; et al. Circulating Tumor DNA Reveals Genetics, Clonal Evolution, and Residual Disease in Classical Hodgkin Lymphoma. Blood 2018, 131, 2413-2425, doi:10.1182/blood-2017-11-812073.

138. Camus, V.; Stamatoullas, A.; Mareschal, S.; Viailly, P.-J.; Sarafan-Vasseur, N.; Bohers, E.; Dubois, S.; Picquenot, J.M.; Ruminy, P.; Maingonnat, C.; et al. Detection and Prognostic Value of Recurrent Exportin 1 Mutations in Tumor and Cell-Free Circulating DNA of Patients with Classical Hodgkin Lymphoma. Haematologica 2016, 101, 1094-1101, doi:10.3324/haematol.2016.145102.

139. Baumann, T.; Delgado, J.; Santacruz, R.; Martínez-Trillos, A.; Royo, C.; Navarro, A.; Pinyol, M.; Rozman, M.; Pereira, A.; Villamor, N.; et al. Chronic Lymphocytic Leukemia in the Elderly: Clinico-Biological Features, Outcomes, and Proposal of a Prognostic Model. Haematologica 2014, 99, 1599-1604, doi:10.3324/haematol.2014.107326.

140. Böttcher, S.; Ritgen, M.; Fischer, K.; Stilgenbauer, S.; Busch, R.M.; Fingerle-Rowson, G.; Fink, A.M.; Bühler, A.; Zenz, T.; Wenger, M.K.; et al. Minimal Residual Disease Quantification Is an Independent Predictor of Progression-Free and Overall Survival in Chronic Lymphocytic Leukemia: A Multivariate Analysis from the Randomized GCLLSG CLL8 Trial. J. Clin. Oncol. Off. J. Am. Soc. Clin. Oncol. 2012, 30, 980-988, doi:10.1200/JCO.2011.36.9348.

141. Ghia, P. A Look into the Future: Can Minimal Residual Disease Guide Therapy and Predict Prognosis in Chronic Lymphocytic Leukemia? Hematol. Am. Soc. Hematol. Educ. Program 2012, 2012, 97-104, doi:10.1182/asheducation-2012.1.97.

142. Strati, P.; Keating, M.J.; O’Brien, S.M.; Burger, J.; Ferrajoli, A.; Jain, N.; Tambaro, F.P.; Estrov, Z.; Jorgensen, J.; Challagundla, P.; et al. Eradication of Bone Marrow Minimal Residual Disease May Prompt Early Treatment Discontinuation in CLL. Blood 2014, 123, 3727-3732, doi:10.1182/blood-2013-11-538116.

143. Del Giudice, I.; Raponi, S.; Della Starza, I.; De Propris, M.S.; Cavalli, M.; De Novi, L.A.; Cappelli, L.V.; Ilari, C.; Cafforio, L.; Guarini, A.; et al. Minimal Residual Disease in Chronic Lymphocytic Leukemia: A New Goal? Front. Oncol. 2019, 9, 689, doi:10.3389/fonc.2019.00689.

144. Landgren, O.; Kyle, R.A.; Pfeiffer, R.M.; Katzmann, J.A.; Caporaso, N.E.; Hayes, R.B.; Dispenzieri, A.; Kumar, S.; Clark, R.J.; Baris, D.; et al. Monoclonal Gammopathy of Undetermined Significance (MGUS) Consistently Precedes Multiple Myeloma: A Prospective Study. Blood 2009, 113, 5412-5417, doi:10.1182/blood-2008-12-194241.

145. Kumar, S.K.; Dispenzieri, A.; Lacy, M.Q.; Gertz, M.A.; Buadi, F.K.; Pandey, S.; Kapoor, P.; Dingli, D.; Hayman, S.R.; Leung, N.; et al. Continued Improvement in Survival in Multiple Myeloma: Changes in Early Mortality and Outcomes in Older Patients. Leukemia 2014, 28, 1122-1128, doi:10.1038/leu.2013.313.

146. Kumar, S.; Paiva, B.; Anderson, K.C.; Durie, B.; Landgren, O.; Moreau, P.; Munshi, N.; Lonial, S.; Bladé, J.; Mateos, M.-V.; et al. International Myeloma Working Group Consensus Criteria for Response and Minimal Residual Disease Assessment in Multiple Myeloma. Lancet Oncol. 2016, 17, e328-e346, doi:10.1016/S1470-2045(16)30206-6.

147. Flores-Montero, J.; Sanoja-Flores, L.; Paiva, B.; Puig, N.; García-Sánchez, O.; Böttcher, S.; van der Velden, V.H.J.; PérezMorán, J.-J.; Vidriales, M.-B.; García-Sanz, R.; et al. Next Generation Flow for Highly Sensitive and Standardized Detection of Minimal Residual Disease in Multiple Myeloma. Leukemia 2017, 31, 2094-2103, doi:10.1038/leu.2017.29.

148. Anderson, K.C.; Auclair, D.; Kelloff, G.J.; Sigman, C.C.; Avet-Loiseau, H.; Farrell, A.T.; Gormley, N.J.; Kumar, S.K.; Landgren, O.; Munshi, N.C.; et al. The Role of Minimal Residual Disease Testing in Myeloma Treatment Selection and Drug Development: Current Value and Future Applications. Clin. Cancer Res. 2017, 23, 3980-3993, doi:10.1158/1078-0432.CCR-162895.

149. Kubaczkova, V.; Vrabel, D.; Sedlarikova, L.; Besse, L.; Sevcikova, S. Cell-Free DNA - Minimally Invasive Marker of Hematological Malignancies. Eur. J. Haematol. 2017, 99, 291-299, doi:10.1111/ejh.12925. 
150. Wong, S.W.; Shah, N.; Ledergor, G.; Martin, T.; Wolf, J.; Shui, A.M.; Huang, C.-Y.; Martinez-Lopez, J. Early Dynamics and Depth of Response in Multiple Myeloma Patients Treated With BCMA CAR-T Cells. Front. Oncol. 2021, 11, 783703, doi:10.3389/fonc.2021.783703.

151. Bolli, N.; Avet-Loiseau, H.; Wedge, D.C.; Van Loo, P.; Alexandrov, L.B.; Martincorena, I.; Dawson, K.J.; Iorio, F.; NikZainal, S.; Bignell, G.R.; et al. Heterogeneity of Genomic Evolution and Mutational Profiles in Multiple Myeloma. Nat. Commun. 2014, 5, 2997, doi:10.1038/ncomms3997.

152. Walker, B.A.; Wardell, C.P.; Melchor, L.; Brioli, A.; Johnson, D.C.; Kaiser, M.F.; Mirabella, F.; Lopez-Corral, L.; Humphray, S.; Murray, L.; et al. Intraclonal Heterogeneity Is a Critical Early Event in the Development of Myeloma and Precedes the Development of Clinical Symptoms. Leukemia 2014, 28, 384-390, doi:10.1038/leu.2013.199.

153. Ghobrial, I.M. Myeloma as a Model for the Process of Metastasis: Implications for Therapy. Blood 2012, 120, 20-30, doi:10.1182/blood-2012-01-379024.

154. Zhang, L.; Beasley, S.; Prigozhina, N.L.; Higgins, R.; Ikeda, S.; Lee, F.Y.; Marrinucci, D.; Jia, S. Detection and Characterization of Circulating Tumour Cells in Multiple Myeloma. J. Circ. Biomark. 2016, 5, 10, doi:10.5772/64124.

155. Lohr, J.G.; Kim, S.; Gould, J.; Knoechel, B.; Drier, Y.; Cotton, M.J.; Gray, D.; Birrer, N.; Wong, B.; Ha, G.; et al. Genetic Interrogation of Circulating Multiple Myeloma Cells at Single-Cell Resolution. Sci. Transl. Med. 2016, 8, 363ra147-363ra147, doi:10.1126/scitranslmed.aac7037.

156. Foulk, B.; Schaffer, M.; Gross, S.; Rao, C.; Smirnov, D.; Connelly, M.C.; Chaturvedi, S.; Reddy, M.; Brittingham, G.; Mata, M.; et al. Enumeration and Characterization of Circulating Multiple Myeloma Cells in Patients with Plasma Cell Disorders. Br. J. Haematol. 2018, 180, 71-81, doi:10.1111/bjh.15003.

157. Garcés, J.-J.; Simicek, M.; Vicari, M.; Brozova, L.; Burgos, L.; Bezdekova, R.; Alignani, D.; Calasanz, M.-J.; Growkova, K.; Goicoechea, I.; et al. Transcriptional Profiling of Circulating Tumor Cells in Multiple Myeloma: A New Model to Understand Disease Dissemination. Leukemia 2020, 34, 589-603, doi:10.1038/s41375-019-0588-4.

158. Ntanasis-Stathopoulos, I.; Gavriatopoulou, M.; Terpos, E.; Fotiou, D.; Kastritis, E.; Dimopoulos, M.A. Monitoring Plasma Cell Dyscrasias With Cell-Free DNA Analysis. Clin. Lymphoma Myeloma Leuk. 2020, 20, e905-e909, doi:10.1016/j.clml.2020.06.025.

159. Sata, H.; Shibayama, H.; Maeda, I.; Habuchi, Y.; Nakatani, E.; Fukushima, K.; Fujita, J.; Ezoe, S.; Tadokoro, S.; Maeda, T.; et al. Quantitative Polymerase Chain Reaction Analysis with Allele-Specific Oligonucleotide Primers for Individual IgH VDJ Regions to Evaluate Tumor Burden in Myeloma Patients. Exp. Hematol. 2015, 43, 374-381.e2, doi:10.1016/j.exphem.2015.01.002. 160. Oberle, A.; Brandt, A.; Voigtlaender, M.; Thiele, B.; Radloff, J.; Schulenkorf, A.; Alawi, M.; Akyüz, N.; März, M.; Ford, C.T.; et al. Monitoring Multiple Myeloma by Next-Generation Sequencing of V(D)J Rearrangements from Circulating Myeloma Cells and Cell-Free Myeloma DNA. Haematologica 2017, 102, 1105-1111, doi:10.3324/haematol.2016.161414.

161. Mithraprabhu, S.; Khong, T.; Ramachandran, M.; Chow, A.; Klarica, D.; Mai, L.; Walsh, S.; Broemeling, D.; Marziali, A.; Wiggin, M.; et al. Circulating Tumour DNA Analysis Demonstrates Spatial Mutational Heterogeneity That Coincides with Disease Relapse in Myeloma. Leukemia 2017, 31, 1695-1705, doi:10.1038/leu.2016.366.

162. Rustad, E.H.; Coward, E.; Skytøen, E.R.; Misund, K.; Holien, T.; Standal, T.; Børset, M.; Beisvag, V.; Myklebost, O.; MezaZepeda, L.A.; et al. Monitoring Multiple Myeloma by Quantification of Recurrent Mutations in Serum. Haematologica 2017, 102, 1266-1272, doi:10.3324/haematol.2016.160564.

163. Gerber, B.; Manzoni, M.; Spina, V.; Bruscaggin, A.; Lionetti, M.; Fabris, S.; Barbieri, M.; Ciceri, G.; Pompa, A.; Forestieri, G.; et al. Circulating Tumor DNA as a Liquid Biopsy in Plasma Cell Dyscrasias. Haematologica 2018, 103, e245-e248, doi:10.3324/haematol.2017.184358.

164. Biancon, G.; Gimondi, S.; Vendramin, A.; Carniti, C.; Corradini, P. Noninvasive Molecular Monitoring in Multiple Myeloma Patients Using Cell-Free Tumor DNA. J. Mol. Diagn. 2018, 20, 859-870, doi:10.1016/j.jmoldx.2018.07.006.

165. Kis, O.; Kaedbey, R.; Chow, S.; Danesh, A.; Dowar, M.; Li, T.; Li, Z.; Liu, J.; Mansour, M.; Masih-Khan, E.; et al. Circulating 
Tumour DNA Sequence Analysis as an Alternative to Multiple Myeloma Bone Marrow Aspirates. Nat. Commun. 2017, 8, 15086, doi:10.1038/ncomms15086.

166. Vrabel, D.; Sedlarikova, L.; Besse, L.; Rihova, L.; Bezdekova, R.; Almasi, M.; Kubaczkova, V.; Brožová, L.; Jarkovsky, J.; Plonkova, H.; et al. Dynamics of Tumor-specific CfDNA in Response to Therapy in Multiple Myeloma Patients. Eur. J. Haematol. 2020, 104, 190-197, doi:10.1111/ejh.13358.

167. Mithraprabhu, S.; Morley, R.; Khong, T.; Kalff, A.; Bergin, K.; Hocking, J.; Savvidou, I.; Bowen, K.M.; Ramachandran, M.; Choi, K.; et al. Monitoring Tumour Burden and Therapeutic Response through Analysis of Circulating Tumour DNA and Extracellular RNA in Multiple Myeloma Patients. Leukemia 2019, 33, 2022-2033, doi:10.1038/s41375-019-0469-x.

168. Deshpande, S.; Tytarenko, R.G.; Wang, Y.; Boyle, E.M.; Ashby, C.; Schinke, C.D.; Thanendrarajan, S.; Zangari, M.; Zhan, F.; Davies, F.E.; et al. Monitoring Treatment Response and Disease Progression in Myeloma with Circulating Cell-free DNA. Eur. J. Haematol. 2021, 106, 230-240, doi:10.1111/ejh.13541.

169. Manzoni, M.; Pompa, A.; Fabris, S.; Pelizzoni, F.; Ciceri, G.; Seia, M.; Ziccheddu, B.; Bolli, N.; Corradini, P.; Baldini, L.; et al. Limits and Applications of Genomic Analysis of Circulating Tumor DNA as a Liquid Biopsy in Asymptomatic Forms of Multiple Myeloma. HemaSphere 2020, 4, e402, doi:10.1097/HS9.0000000000000402.

170. Pugh, T.J. Circulating Tumour DNA for Detecting Minimal Residual Disease in Multiple Myeloma. Semin. Hematol. 2018, 55, 38-40, doi:10.1053/j.seminhematol.2018.03.002.

171. Mazzotti, C.; Buisson, L.; Maheo, S.; Perrot, A.; Chretien, M.-L.; Leleu, X.; Hulin, C.; Manier, S.; Hébraud, B.; Roussel, M.; et al. Myeloma MRD by Deep Sequencing from Circulating Tumor DNA Does Not Correlate with Results Obtained in the Bone Marrow. Blood Adv. 2018, 2, 2811-2813, doi:10.1182/bloodadvances.2018025197.

172. Long, X.; Xu, Q.; Lou, Y.; Li, C.; Gu, J.; Cai, H.; Wang, D.; Xu, J.; Li, T.; Zhou, X.; et al. The Utility of Non-invasive Liquid Biopsy for Mutational Analysis and Minimal Residual Disease Assessment in Extramedullary Multiple Myeloma. Br. J. Haematol. 2020, 189, doi:10.1111/bjh.16440.

173. Manier, S.; Park, J.; Capelletti, M.; Bustoros, M.; Freeman, S.S.; Ha, G.; Rhoades, J.; Liu, C.J.; Huynh, D.; Reed, S.C.; et al. Whole-Exome Sequencing of Cell-Free DNA and Circulating Tumor Cells in Multiple Myeloma. Nat. Commun. 2018, 9, 1691, doi:10.1038/s41467-018-04001-5.

174. Guo, G.; Raje, N.S.; Seifer, C.; Kloeber, J.; Isenhart, R.; Ha, G.; Yee, A.J.; O’Donnell, E.K.; Tai, Y.-T.; Richardson, P.G.; et al. Genomic Discovery and Clonal Tracking in Multiple Myeloma by Cell-Free DNA Sequencing. Leukemia 2018, 32, 1838-1841, doi:10.1038/s41375-018-0115-z.

175. Waldschmidt, J.M.; Vijaykumar, T.; Knoechel, B.; Lohr, J.G. Tracking Myeloma Tumor DNA in Peripheral Blood. Best Pract. Res. Clin. Haematol. 2020, 33, 101146, doi:10.1016/j.beha.2020.101146.

176. Mithraprabhu, S.; Spencer, A. Circulating Tumour DNA Analysis in Multiple Myeloma. Oncotarget 2017, 8, 90610-90611, doi:10.18632/oncotarget.21595.

177. Medina Diaz, I.; Nocon, A.; Mehnert, D.H.; Fredebohm, J.; Diehl, F.; Holtrup, F. Performance of Streck CfDNA Blood Collection Tubes for Liquid Biopsy Testing. PloS One 2016, 11, e0166354, doi:10.1371/journal.pone.0166354.

178. Franczak, C.; Filhine-Tresarrieu, P.; Gilson, P.; Merlin, J.-L.; Au, L.; Harlé, A. Technical Considerations for Circulating Tumor DNA Detection in Oncology. Expert Rev. Mol. Diagn. 2019, 19, 121-135, doi:10.1080/14737159.2019.1568873. 